\title{
Application of Neural Network-Support Vector Technique to Forecast U.S. Unemployment Rate
}

\author{
Azadeh Ansari
}

Follow this and additional works at: https://researchrepository.wvu.edu/etd

\section{Recommended Citation}

Ansari, Azadeh, "Application of Neural Network-Support Vector Technique to Forecast U.S. Unemployment Rate" (2014). Graduate Theses, Dissertations, and Problem Reports. 5112.

https://researchrepository.wvu.edu/etd/5112

This Thesis is protected by copyright and/or related rights. It has been brought to you by the The Research Repository @ WVU with permission from the rights-holder(s). You are free to use this Thesis in any way that is permitted by the copyright and related rights legislation that applies to your use. For other uses you must obtain permission from the rights-holder(s) directly, unless additional rights are indicated by a Creative Commons license in the record and/ or on the work itself. This Thesis has been accepted for inclusion in WVU Graduate Theses, Dissertations, and Problem Reports collection by an authorized administrator of The Research Repository @ WVU. For more information, please contact researchrepository@mail.wvu.edu. 


\title{
Application of Neural Network-Support Vector Technique to Forecast U.S. Unemployment Rate
}

\author{
Azadeh Ansari \\ Thesis submitted to the Benjamin M. Statler College of Engineering and Mineral \\ Resources at West Virginia University
}

in partial fulfillment of the requirements for the degree of

\author{
Master of Science in \\ Industrial Engineering
}

\author{
Rashpal S. Ahluwalia, Ph.D., Chair \\ Robert C. Creese, Ph.D. \\ Feng Yang, Ph.D.
}

Department of Industrial and Management Systems Engineering

\author{
Morgantown, West Virginia
}

2014

Keyword: Support Vector Regression, Neural Networks, Unemployment, Prediction 


\section{ABSTRACT}

\section{Application of Neural Network-Support Vector Technique to Forecast U.S. Unemployment Rate}

\section{Azadeh Ansari}

This research utilized five economic factors; 1) Consumer Price Index, 2) Return on Treasury Securities, 3) Total Nonfarm payroll, 4) Jobless Claims Filed, and 5) Stand \& Poor 500 index to predict US unemployment rate. Historical time series data was obtained from the Economic Research web site of the Federal Reserve Bank of St. Louis and other finance web site.

Multiple Linear Regression, Back Propagation Algorithm, and Support Vector Regression techniques were utilized to predict US unemployment rate. Based on Mean Squared Error and adjusted R2 values, the Support Vector Regression technique provided superior results for the given dataset. Future US unemployment rate was predicted with an average absolute error value of 0.815, 0.13 and 0.07 using MLR, ANN and SVR, respectively. 


\section{Table of Contents}

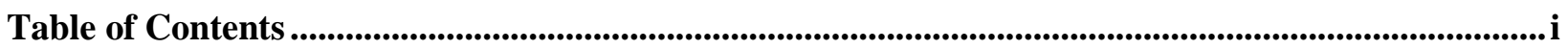

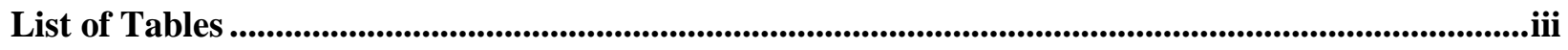

List of Figures.......................................................................................................................................................... iv

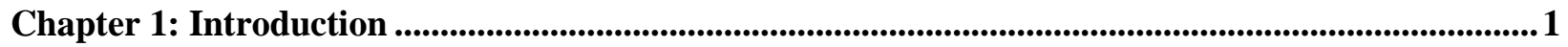

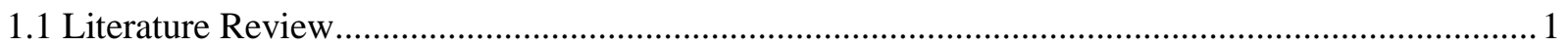

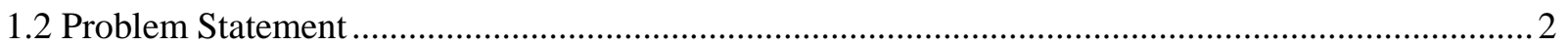

Chapter 2: Prediction Methods ...............................................................................................................................3

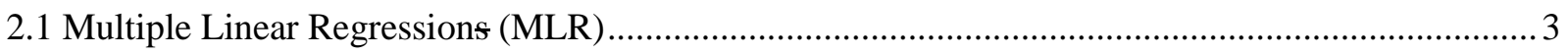

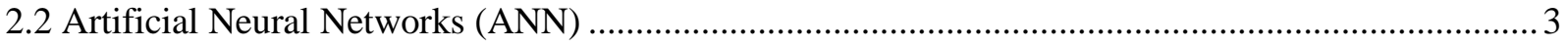

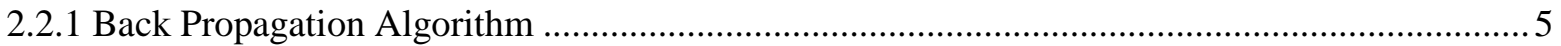

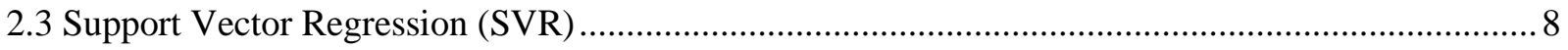

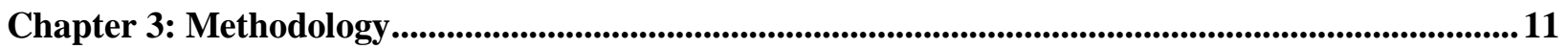

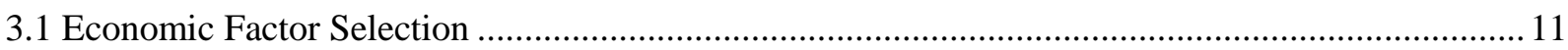

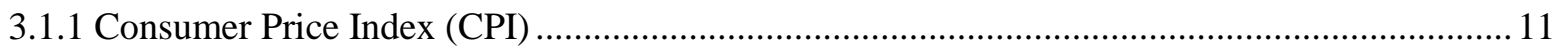

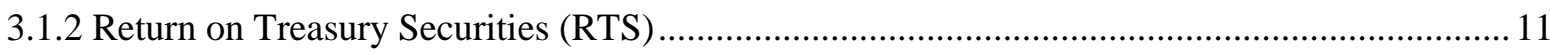

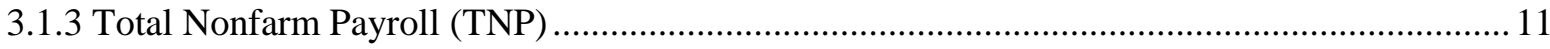

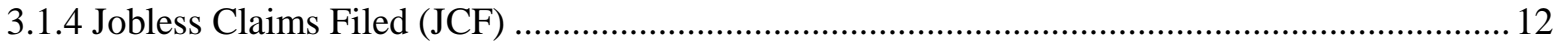

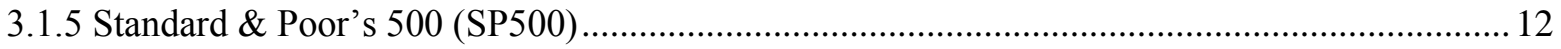

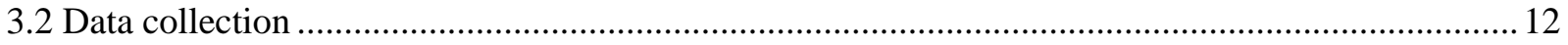

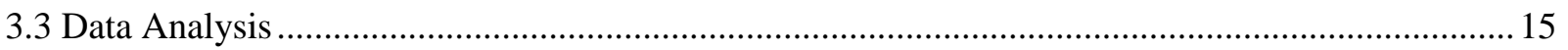

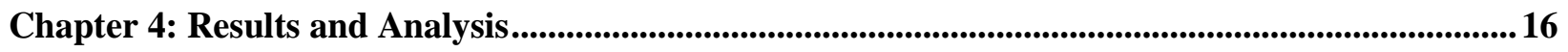

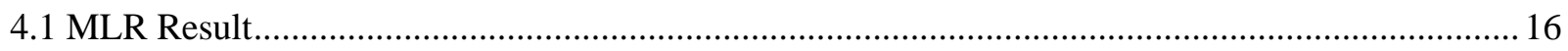

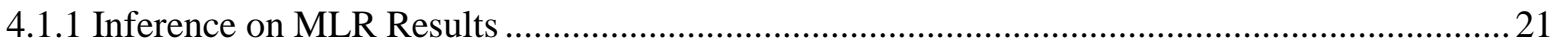

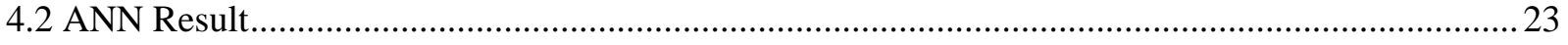

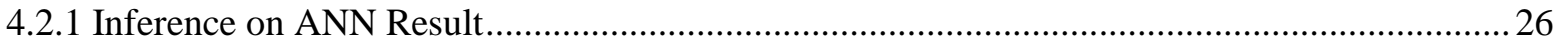

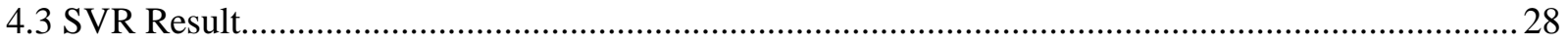

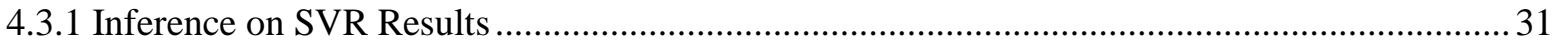

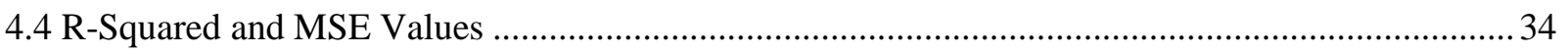

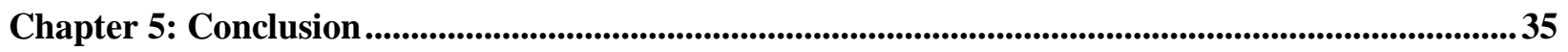

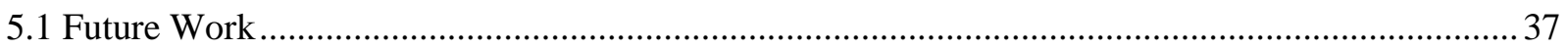




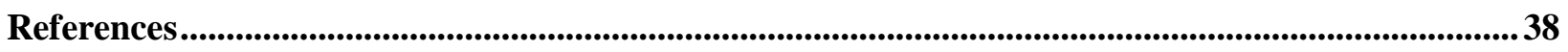

Appendix A: Input Data ..............................................................................................................................41

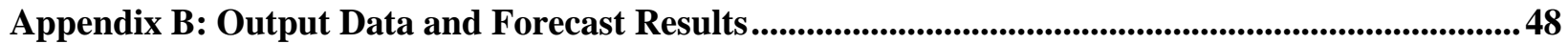




\section{List of Tables}

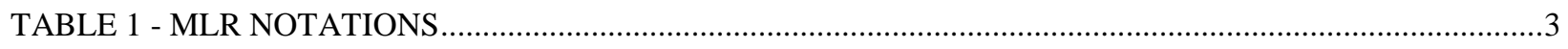

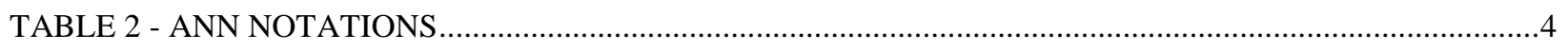

TABLE 3 - SVR NOTATIONS ……................................................................................................

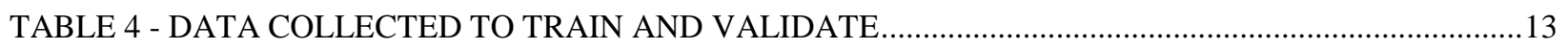

TABLE 5 - DESCRIPTIVE STATISTICS ON DATA FOR FIVE FACTORS ………….......................................13

TABLE 6 - LINEAR REGRESSION PARAMETERS WHEN JCF IS IN MODEL...............................................16

TABLE 7 - LINEAR REGRESSION PARAMETER WHEN RTS MOVES INTO THE MODEL.............................17

TABLE 8 - LINEAR REGRESSION PARAMETER WHEN TNP MOVES INTO THE MODEL ...........................17

TABLE 9 - LINEAR REGRESSION PARAMETER WHEN CPI MOVES INTO THE MODEL.............................17

TABLE 10 - LINEAR REGRESSION PARAMETERS WHEN SP500 MOVES INTO THE MODEL ....................18

TABLE 11 - ANALYSIS OF VARIANCE FOR REGRESSION MODEL ……...............................................18

TABLE 12 - PREDICTION INTERVAL ON MLR RESULTS ….........................................................................21

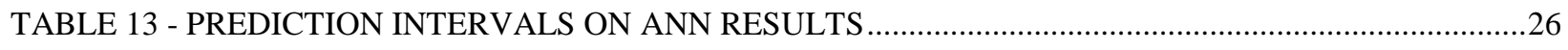

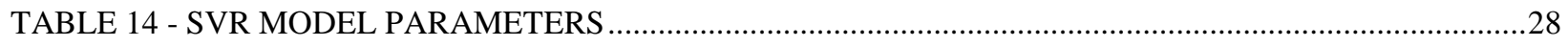

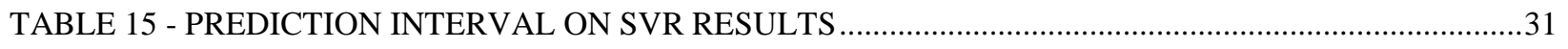

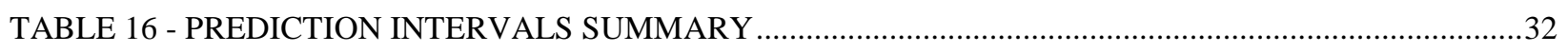

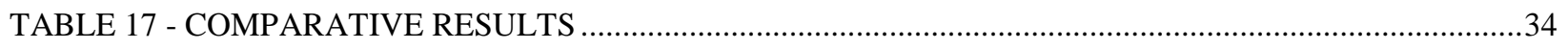

TABLE 18 - FUTURE FORECAST BASED ON THE TRAINED MODELS ....................................................... 


\section{List of Figures}

FIGURE 1-ARTIFICIAL NEURAL NETWORKS STRUCTURE ………......................................................

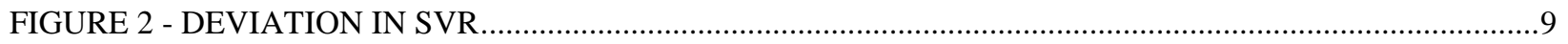

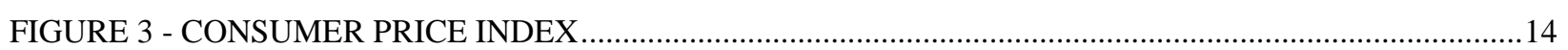

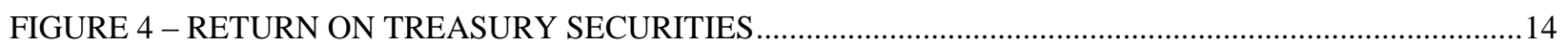

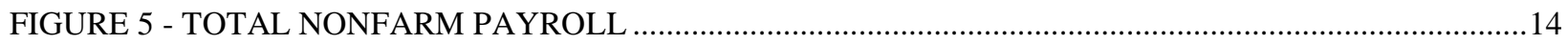

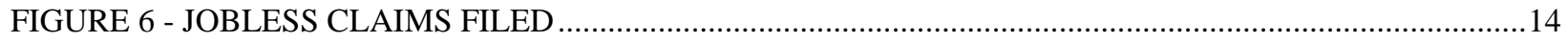

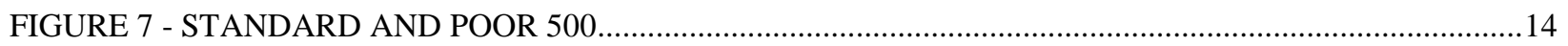

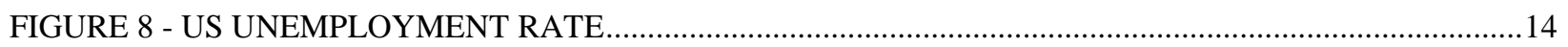

FIGURE 9 - MLR TRAINING RESULT VS ACTUAL UNEMPLOYMENT ……...................................................19

FIGURE 10 - MLR TEST RESULT VS ACTUAL UNEMPLOYMENT ……......................................................20

FIGURE 11 - ANN TRAINING RESULT VS ACTUAL UNEMPLOYMENT ……………….............................24

FIGURE 12 - ANN TEST RESULT VS ACTUAL UNEMPLOYMENT …................................................................25

FIGURE 13 - SVR TRAINING RESULT VS ACTUAL UNEMPLOYMENT ....................................................29

FIGURE 14 - SVR TEST RESULT VS ACTUAL UNEMPLOYMENT ..............................................................30

FIGURE 15 - TEST RESULTS FOR ALL TECHNIQUES VS. ACTUAL UNEMPLOYMENT .............................36 


\section{Chapter 1: Introduction}

\subsection{Literature Review}

Time series analysis and Okun's law are two basic approaches used to forecast unemployment rate. The time series data is an ordered sequence of values of a variable at equally spaced time intervals. The time series forecasting approach deals with developing models to predict future values based on time series data. The Okun's law approach is based on developing a statistical relationship between the unemployment rate and the rate of production losses. It is not based on time series data. Usually, there is a positive relationship between the Gross Domestic Product (GDP) and employment since the value of labor in the production defines the GDP. Okun's law states that GDP will decrease approximately $2 \%$ when unemployment increases for by $1 \%$ (Baily and Okun, 1965).

Time-Series Forecasting has three main tasks: 1) Develop a best possible model that relates available features to the unknown variable, 2) Use the model to predict the unknown variable, and 3) Obtain major properties of the model (Characterization). The three tasks may overlap with each other (Weigend and Gershenfeld, 1992).

The relationship between independent factors and unemployment rate can be linear or nonlinear. Many models presented in the literature assume a linear relationship. Proietti (2003) has explored performance of linear and nonlinear structural time series models of the US unemployment rate utilizing a test period of the last two decades. Studies, such as Altissimo and Violante (2001), Caner and Hansen (2001), Milas and Rothman (2008) utilized nonlinear models. Appropriate model selection and dependency of data are major problem in using nonlinear models. Olmedo (2014) used two different nonlinear models called reconstruction approach and Artificial Neural Networks (ANN) to predict Spanish unemployment rate and concluded that ANN outperformed the reconstruction approach in predicting Spanish unemployment rate.

Rothman (1998) analyzed the performance of six different nonlinear time series models versus linear model predictions and concluded that the nonlinear models perform much better based on Mean Squared Prediction Error (MSPE). Montgomery et al. (1998) compared the 
performance of different linear and nonlinear forecasting techniques using U.S. quarterly unemployment rate. Voineagu et al. (2012) developed a method to forecast the monthly unemployment rate which also highlights the seasonality of the data.

\subsection{Problem Statement}

The purpose of this study is to apply three different techniques to predict U.S. unemployment rate based on the historical data published by U.S. government. The three methods are: 1) Multiple Linear Regression (MLR), 2) Artificial Neural Networks (ANN), and 3) Support Vector Regression (SVR). The results of all three methods will be compared using R-Squared and MSE values to determine which technique is better suited to predict U.S. unemployment rate.

The main contribution of this study was identification of five economic factors: 1) Consumer Price Index (CPI), 2) Returned on Treasury Securities (RTS), 3) Total Nonfarm Payroll (TNP), 4) Jobless Claims Filed (JCF), and 5) Standard and Poor's 500 (SP500). The study applied three different methods on the same data set to predict US unemployment rate. Thus far, neither time series nor Okun's law have used the above five economic factors to forecast US unemployment rate. 


\section{Chapter 2: Prediction Methods}

\subsection{Multiple Linear Regressions (MLR)}

Multiple linear regression is a multivariate statistical technique to study the linear correlations of a dependent variable (Y) with two or more independent variables (Xs). Table 1 shows all the notations for this method.

Table 1 - MLR Notations

\begin{tabular}{|c|l|}
\hline Notation & Description \\
\hline $\mathrm{Y}$ & Dependent Variable in the Regression Model \\
\hline$i$ & Independent Variable Index \\
\hline$X_{i}$ & Independent Variable $i$ in the Regression Model \\
\hline$\beta_{0}$ & Intercept of the regression model \\
\hline$\beta_{\mathrm{i}}$ & Coefficient of Variable $i$ in the Regression Model \\
\hline$\varepsilon$ & Random Error Term \\
\hline
\end{tabular}

The general form of the model is shown in Equation 1.

$$
Y=\beta_{0}+\beta_{1} X_{1}+\beta_{2} X_{2}+\cdots+\beta_{n} X_{n}+\varepsilon
$$

$\varepsilon$ represents the error term of the model and usually follows the normal distribution. $\beta_{0}$ is the intercept and $\beta_{1}, \beta_{2}, \ldots, \beta_{n}$ are the coefficients related to factors $X_{1}, X_{2}, \ldots, X_{n}$ in the model, respectively. The independent variable $\left(X_{i}\right)$ represent the value of variable $i$. Generalized least squares method is used to determine the coefficients of the model (Kissock et al., 2003). In this study, the U.S. unemployment rate is the dependent variable.

\subsection{Artificial Neural Networks (ANN)}

ANNs are computational models developed by Mcculloch et al. (1943). These models are based on neural networks in human brains. It consists of neurons and connections which are assigned a specific weight. The idea is to find appropriate weights for connections such an acceptable output can be gained for each corresponding input (Duda, et al., 2012). A neural network model also consists of layers. Each layer contains number of nodes. The first and last 
layers are called input and output layer respectively. Hidden layers are between input and output layers. Each node in a layer has inputs and generates an output based on an activation function (Duda, et al., 2012). The notations need for this method are listed in Table 2.

Table 2 - ANN Notations

\begin{tabular}{|c|l|}
\hline Notation & Description \\
\hline $\mathrm{i}$ & Indexes unit in input layer or the feature number \\
\hline $\mathrm{h}$ & Indexes unit in hidden layer \\
\hline Net $_{\mathrm{h}}$ & Scalar net activation of neuron $\mathrm{k}$ in hidden layer \\
\hline $\mathrm{H}$ & Number of neurons in hidden layer \\
\hline $\mathrm{Net}_{\mathrm{o}}$ & Scalar net activation of output layer \\
\hline $\mathrm{OU}_{\mathrm{i}}$ & Output of neuron $\mathrm{i}$ in input layer \\
\hline $\mathrm{OU}_{\mathrm{h}}$ & Output of neuron $\mathrm{k}$ in hidden layer \\
\hline$\delta$ & Sensitivity of neuron at output layer \\
\hline$\delta_{\mathrm{k}}$ & Sensitivity of neuron $\mathrm{k}$ at hidden layer \\
\hline $\mathrm{L}$ & Learning rate \\
\hline $\mathrm{M}$ & Number of data points \\
\hline $\mathrm{u}$ & $\mathrm{u}$-th pattern \\
\hline $\mathrm{x}$ & Space of input patterns \\
\hline $\mathrm{y}$ & Output vector \\
\hline $\mathrm{T}$ & Target Vector \\
\hline $\mathrm{E}$ & Error function in ANNs \\
\hline $\mathrm{Tre}$ & Accepted error for BP \\
\hline $\mathrm{r}$ & r-th epoch in back propagation algorithm \\
\hline $\mathrm{W}$ & Weight for connection from neuron i to neuron $\mathrm{k}$ in hidden layer \\
\hline $\mathrm{W}$ & Weight for connection from neuron $\mathrm{k}$ in hidden layer to output layer \\
\hline
\end{tabular}


Different activation functions are shown in Equations 2, 3 and 4. Figure 1 shows the overall structure of the model.

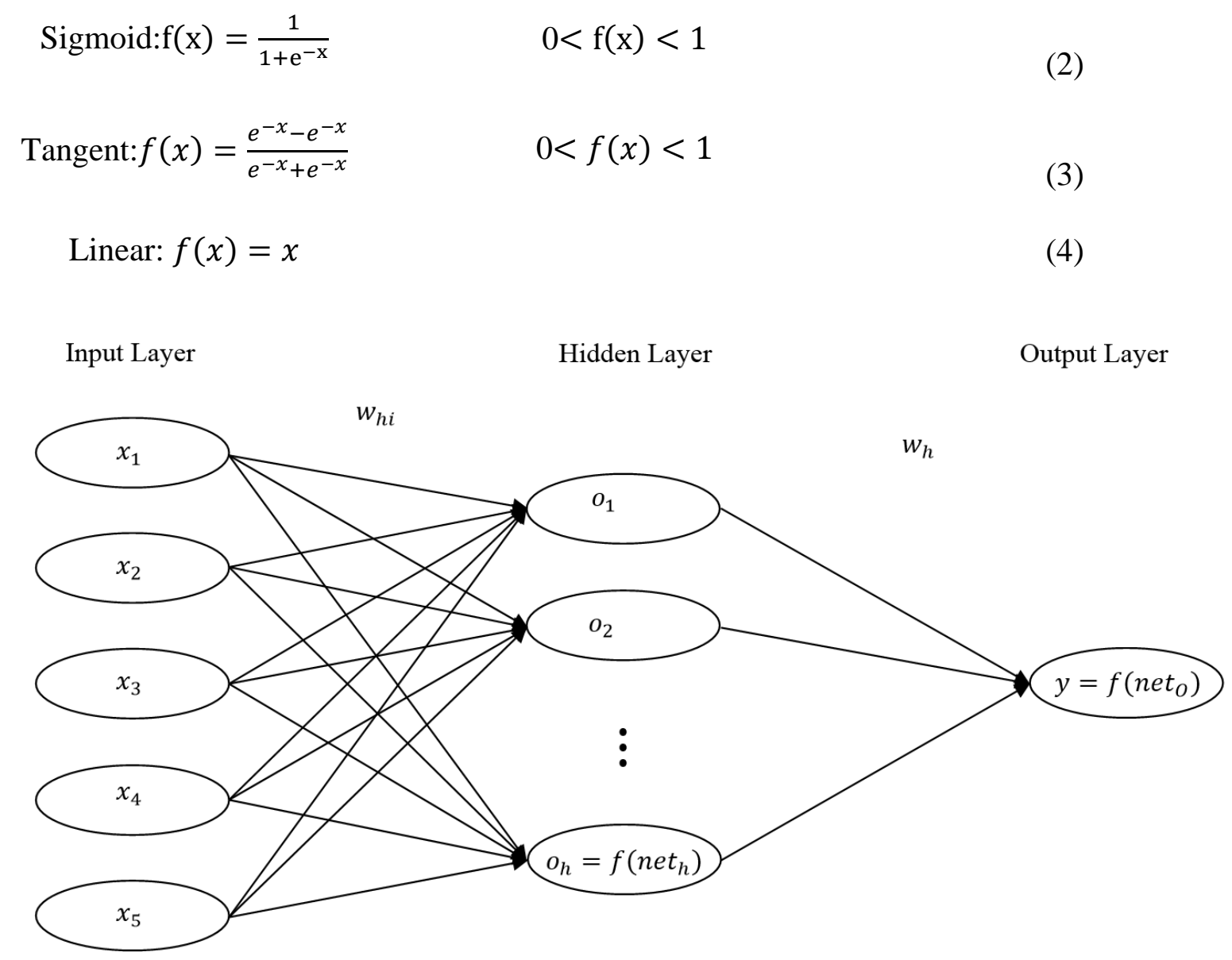

Figure 1-Artificial Neural Networks Structure

Input layer consists of five features demonstrating five factors. $w_{h i}$ represents the weight for the connection between neuron $i$ in input layer and neuron $h$ in hidden layer and $w_{h}$ shows the weights of the connections between neuron $h$ in hidden layer and the single neuron in the output layer. net $_{h}$ and $n e t_{O}$ are the scalar net activation of neuron $h$ in hidden layer and the neuron in the output layer, respectively.

\subsubsection{Back Propagation Algorithm}

After the weights are initialized, neural network utilizes Back Propagation Algorithm (BPA) to train the network. The back propagation algorithm was developed by Rumelhart (1988) and it 
is the most popular technique to train neural networks. The algorithm starts with an untrained network and explores better weight through using gradient descent algorithm. The BPA algorithm utilizes the error back propagated from the output layer to change weights. On each epoch of the algorithm outputs of the nodes are obtained based on weight of connections between nodes. The BPA can be summarized as following steps.

\section{Feed Forward}

Feed Forward is the first step in which the output of each neuron in hidden layer $\left(O U_{h}\right)$ will be obtained using Equation 6. Equations 5 and 7 calculate scalar net activation of neuron $h$ in hidden layer $\left(\right.$ net $\left._{h}\right)$ and the scalar net activation of the single neuron in the output layer $\left(\right.$ net $\left._{o}\right)$, respectively.

$$
\begin{gathered}
\operatorname{net}_{h}=\sum_{i=0}^{5} x_{i} w_{h i} \\
o U_{h}=f\left(\text { net }_{h}\right) \\
\text { net }_{O}=\sum_{h} O U_{h} w_{h}
\end{gathered}
$$

\section{Feed Backward}

Finally, Equation 8 is used to calculate the result of the output layer:

$$
y=f\left(\text { net }_{o}\right)
$$

In this step, the network error is back propagated from output layer to input layer. The sensitivity $(\delta)$ is calculated for the output node based on Equation 9 where $t$ is the target value and $y$ is the forecast value:

$$
\delta=y(1-y)(y-t)
$$


According to Duda et al. (2012), the sensitivity of neuron $h$ in hidden layer can be calculated for each node in hidden layer as shown in Equation 10.

$$
\delta_{\mathrm{h}}=\mathrm{OU}_{\mathrm{k}}\left(1-\mathrm{OU}_{\mathrm{k}}\right) \delta w_{h}
$$

Cost function is calculated using Equation 11. According to Equations 7 and 8, the network output is a function of weight vectors. Thus, cost is the function of $\mathrm{w}_{\mathrm{h}}$ and $\mathrm{w}_{\mathrm{hi}}$ where $h=$ $1, \ldots, H$ and $i=1, \ldots, 5$.

$$
\mathrm{E}=\frac{1}{2}(y-t)^{2}
$$

According to Duda et al. (2012), the BPA can be represented as follows where $L$ is learning rate, $r$ is the epoch number and Tre is the acceptable error or threshold value:

\section{Back Propagation Algorithm}

1. Initialize $w, L$ and $r=0$

2. Do $r \leftarrow r+1$ (Update epoch)

3. $u \leftarrow 0 ; \Delta w_{h i} \leftarrow 0 ; \Delta w_{h} \leftarrow 0$

4. Do $u \leftarrow u+1$

5. $x_{u} \leftarrow$ select pattern

6. $\Delta w_{h i} \leftarrow \Delta w_{h i}+L . \delta_{\mathrm{h}} \cdot x_{i} ; \Delta w_{h} \leftarrow \Delta w_{h}+L . \delta . y$

7. Until $u=M$

8. $\quad w_{h i} \leftarrow w_{h i}+\Delta w_{h i} ; w_{h} \leftarrow w_{h}+\Delta w_{h}$

9. Until ||$\nabla E(w) \|<\operatorname{Tre}, \nabla E(w)=E_{r+1}(w)-E_{r}(w)$

10. Return $w$

11. End 


\subsection{Support Vector Regression (SVR)}

Table 3 shows the notations for variables and parameters needed in this method.

Table 3 - SVR Notations

\begin{tabular}{|c|l|}
\hline Notation & Description \\
\hline $\mathrm{x}$ & Input vector \\
\hline $\mathrm{t}$ & Target vector \\
\hline $\mathrm{u}$ & Unit index of $\mathrm{u}$-th pattern \\
\hline $\mathrm{V}$ & Unit index of v-th pattern \\
\hline $\mathrm{y}$ & Output vector \\
\hline $\mathrm{N}$ & Number of data points \\
\hline$\epsilon$ & The width of the tube (Acceptable Deviation) \\
\hline $\mathrm{W}$ & Regression line weight vector in SVR \\
\hline $\mathrm{b}$ & Bias term \\
\hline$\zeta_{\mathrm{u}}^{+}$ & Positive deviation from acceptable region for $\mathrm{u}$-th pattern \\
\hline$\zeta_{\mathrm{u}}^{-}$ & Negative deviation from acceptable region for u-th pattern \\
\hline $\mathrm{C}$ & Cost of not falling inside the SVR tube \\
\hline $\mathrm{L}_{\epsilon}$ & Loss function for the tube with width of $\epsilon$ \\
\hline$\varphi$ & The kernel function \\
\hline$\sigma$ & The sigma value of kernel function \\
\hline & \\
\hline &
\end{tabular}

Suppose a training data set is given as $\left\{\left(\mathrm{x}_{1}, \mathrm{t}_{1}\right), \ldots,\left(\mathrm{x}_{\mathrm{u}}, \mathrm{t}_{\mathrm{u}}\right), \ldots,\left(\mathrm{x}_{\mathrm{N}}, \mathrm{t}_{\mathrm{N}}\right)\right\}$ where $\mathrm{x}_{\mathrm{u}} \in \mathrm{R}^{\mathrm{m}}$ is the input vector and $t_{u} \in R$ is the target vector. The main goal is to obtain a flat function $\mathrm{f}(\mathrm{x})$ that has a deviation less than the maximum acceptable deviation $(\varepsilon)$ from the actual targets $t_{u}$ for every pattern of the training data. In other words, the error of each pattern less than $\varepsilon$ is acceptable and deviation of more than $\varepsilon$ is not acceptable.

Equation 12 defines $f\left(x_{u}\right)$ where $w_{S V R}$ is the regression line weight vector of $x_{u}$ in SVR and $b$ is the bias term. To have simpler function, smaller sizes of $w_{S V R}$ are recommended. Figure 2 represents the deviation range and the data patterns where $\epsilon$ is the width of the acceptable tube. (Vapnik, 2000) 


$$
f\left(x_{u}\right)=w_{S V R}^{T} x+b
$$

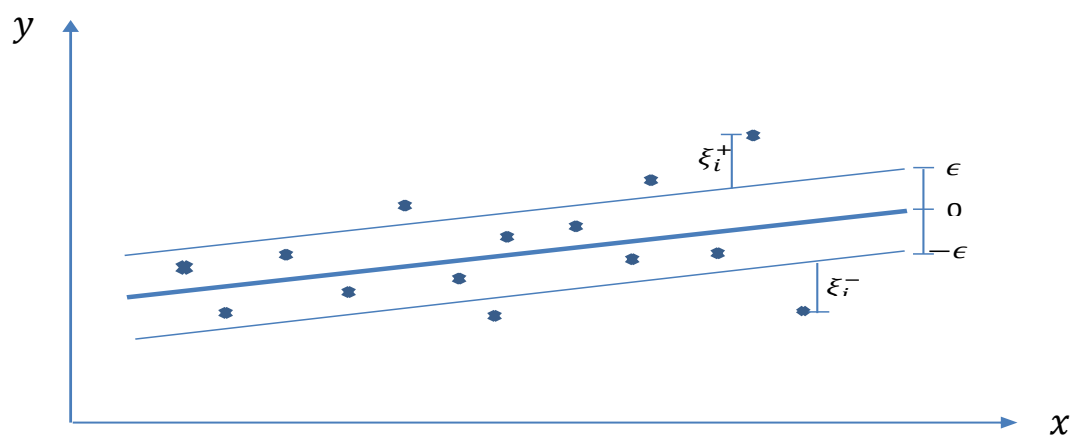

Figure 2 - Deviation in SVR

Equation 13 defines a loss function $L_{\epsilon}$ for a deviation size of $\epsilon$ which assigns a cost $\mathrm{C}$ for point outside of the predefined range (Vapnik, 2000).

$$
L_{\epsilon}(\mathrm{x}, \mathrm{t}, \mathrm{f}(\mathrm{x}))=\left\{\begin{array}{lr}
0 & \text { if }\left|\mathrm{w}_{\mathrm{SVR}}^{\mathrm{T}} \mathrm{x}+\mathrm{b}-t\right| \leq \epsilon \\
\left|\mathrm{w}_{\mathrm{SVR}}^{\mathrm{T}} \mathrm{x}+\mathrm{b}-t\right|-\epsilon & \text { otherwise }
\end{array} \quad \forall u\right.
$$

Equation 14 describes SVR minimization function subject to the constraints shown in Equations 15, 16 and 17. The term $\frac{1}{2} w_{S V R}^{T} w_{S V R}$ in the objective function is to minimize the size of the weights $w_{S V R} \cdot \zeta_{u}^{+}$and $\zeta_{u}^{-}$are positive and negative deviation from acceptable region for the $\mathrm{u}^{\text {th }}$ pattern, respectively. $C$ is the cost of falling outside of the acceptable tube. Thus, the term $c \sum_{i=1}^{N}\left(\zeta_{u}^{+}+\zeta_{u}^{-}\right)$is the trade-off between minimizing the size of the weights and the loss function. A proper value of $\mathrm{C}$ is very important to avoid under-fitting or over-fitting problems (Vapnik, 2000).

$$
\operatorname{minimize} \frac{1}{2} w_{S V R}^{T} w_{S V R}+c \sum_{i=1}^{N}\left(\zeta_{u}^{+}+\zeta_{u}^{-}\right)
$$

Subject to:

$$
\mathrm{w}_{\mathrm{SVR}}^{\mathrm{T}} \mathrm{x}+\mathrm{b}-t_{u}<\epsilon+\zeta_{u}^{+} \quad \forall_{u}
$$




$$
\begin{array}{cc}
t_{u}-\mathrm{w}_{\mathrm{SVR}}^{\mathrm{T}} \mathrm{x}-\mathrm{b}<\epsilon+\zeta_{u}^{-} & \forall_{u} \\
\zeta_{u}^{+}, \zeta_{u}^{-} \geq 0 & \forall_{u}
\end{array}
$$

SVR exploits a kernel function $(\varphi)$ to map $\mathrm{x}_{\mathrm{u}} \in \mathrm{R}^{\mathrm{n}}$ to higher dimensional feature space where theoretically exists a linear function $\mathrm{f}$ to formulate $f(x)$ as a function of input data $\mathrm{x}$ (Duda et al., 2012).

The regression function can be written as shown in Equation 18:

$$
f(x)=w_{S V R} \varphi(x)+b \quad \forall_{u}
$$

The kernel function can be defined using Equation 19:

$$
\varphi\left(x_{u}, x_{v}\right)=\exp \left(-\frac{1}{2 \sigma^{2}}|| x_{u}-x_{v} \|^{2}\right) \quad \forall_{u}
$$

$\sigma$ represents the standard deviation of the kernel function and is user identified. $x_{u}$ and $x_{v}$ are the $\mathrm{u}^{\text {th }}$ and $\mathrm{v}^{\text {th }}$ pattern in the input vector. In this study, complete enumeration (grid SVR) was applied to obtain the value of $\sigma$. 


\section{Chapter 3: Methodology}

\subsection{Economic Factor Selection}

There are lots of economic indicators that can impact unemployment rate in the United States. In this study, five factors were selected for which monthly data is available from January 1993 to June 2014. The five factors are described below.

\subsubsection{Consumer Price Index (CPI)}

The Consumer Price Index (CPI) is defined by the Bureau of the Economic Analysis as a measure of the average monthly change in the price of goods and services paid by urban consumers between any two time periods (Bureau of Economic Analysis, 2013). To calculate the index, price changes are averaged with weights showing their importance in the spending of the particular group. The index measures price changes as a percent change from a predetermined reference date (Bureau of Economic Analysis, 2013). Variations in this index are used to evaluate price changes related to the cost of living. The data on CPI was downloaded from: http://research.stlouisfed.org/fred2/series/CPIAUCSL/.

\subsubsection{Return on Treasury Securities (RTS)}

Federal Reserve Board utilized Constant Maturity (CM) as a correction for equivalent maturity to find an index using the average yield of different Treasury securities maturing at various periods. These rates are released by the U.S. Treasury on a daily basis. In order to get the monthly data, the average method is used. The data on CM was downloaded from: http://research.stlouisfed.org/fred2/series/DGS10/.

\subsubsection{Total Nonfarm Payroll (TNP)}

The U.S. Bureau of Labor Statistics defines Total Nonfarm Payroll (TNP) as a measure of the number of U.S. workers in the economy which does not include proprietors, private household employees, unpaid volunteers, farm employees, and the unincorporated self-employed (Bureau of Labor statistics, 2013). 
TNP represents number of jobs added to or lost in an economy. It can be concluded that the business is growing if employment number increase. This index is seasonally adjusted as the unemployment rate is subject to changes during the year because of different weather conditions, the time schools open and special holidays. The data on TNP was downloaded from: http://research.stlouisfed.org/fred2/series/PAYEMS/.

\subsubsection{Jobless Claims Filed (JCF)}

This index is the number of Jobless Claims Filed (JCF) by those who are willing to receive state jobless benefits. Financial analysts watch this value closely since it gives a good insight about the economy. The higher the initial claims, the weaker the economy. The data on JCF was downloaded from: http://research.stlouisfed.org/fred2/series/IC4WSA/.

\subsubsection{Standard \& Poor's 500 (SP500)}

Standard and Poor's 500 (SP500) is a stock market index that keeps track of the 500 most commonly held stocks on the New York Stock Exchange (NYSE). These 500 stocks can give investors an overview of stock market. The standard and poor's 500 is also considered as an economic indicator and it project the performance of US economy. The data on S\&P 500 was downloaded from: http://finance.yahoo.com.

\subsection{Data collection}

Most of the data are coming from the Federal Reserve Bank of St. Louis. The U.S. unemployment rates as the output of all three methods are also taken from Federal Reserve Bank.

Table 4 shows the matrix of input data to predict two periods ahead unemployment rate. 
Table 4 - Data Collected to train and validate

$\begin{array}{cccccc}\text { DATE } & \text { CPI } & \text { RTS } & \text { TNP } & \text { JCF } & \text { S\&P 500 } \\ \text { Jan-93 } & 142.80 & 6.60 & 109805 & 341200 & 438.78 \\ \text { Feb-93 } & 143.10 & 6.26 & 110047 & 334813 & 443.38 \\ \text { • } & \cdot & \cdot & \cdot & \cdot & \cdot \\ \text { • } & \cdot & \cdot & \cdot & \cdot & \cdot \\ \text { • } & \cdot & \cdot & \cdot & \cdot & \cdot \\ \text { Jun-14 } & 237.69 & 2.60 & 138764 & 314375 & 1960.23\end{array}$

Table 5 shows all the descriptive statistics of five factors on all 258 data points. However, the descriptive statistics for training and test data set need to be calculated separately.

Table 5 - Descriptive Statistics on Data for five Factors

\begin{tabular}{|c|c|c|c|c|c|}
\hline & CPI & RTS & TNP & JCF & SP500 \\
\hline Min & 142.80 & 1.53 & 109805 & 269000 & 438.78 \\
\hline Max & 237.69 & 7.96 & 138764 & 654875 & 1960.23 \\
\hline Mean & 188.45 & 4.62 & 129118.99 & 366856.41 & 1101.60 \\
\hline Std & 28.41 & 1.50 & 7509.95 & 67100.98 & 351.30 \\
\hline Range & 94.89 & 6.43 & 28959 & 385875 & 1521.45 \\
\hline
\end{tabular}

Figures 3 to 8 show the data on each factor from January 1993 to June 2014 in the United States including the unemployment rate. 


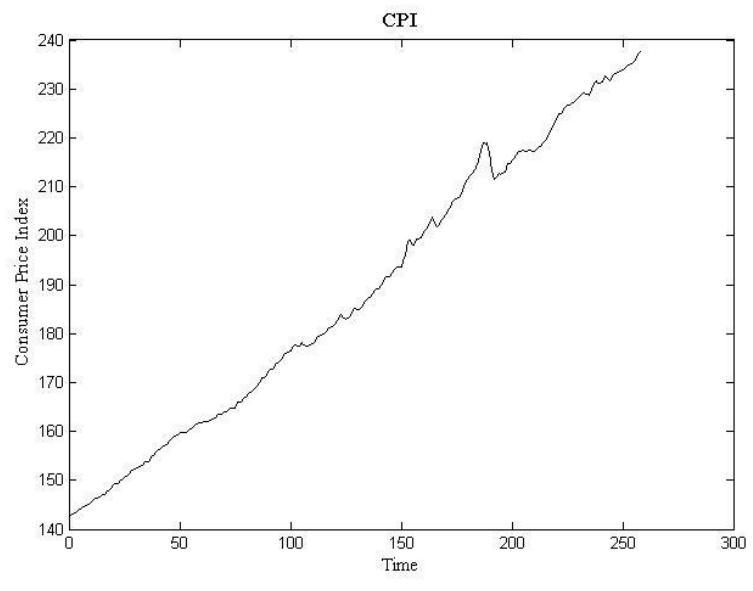

Figure 3 - Consumer Price Index

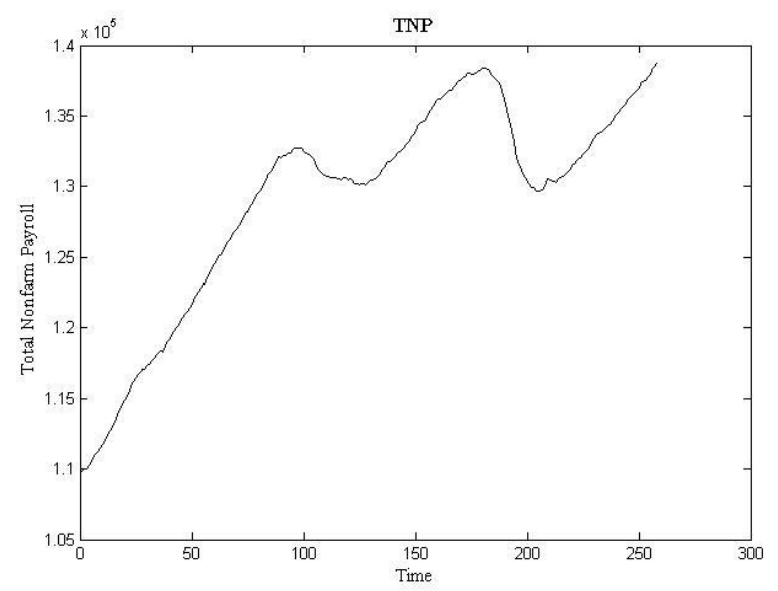

Figure 5 - Total Nonfarm Payroll

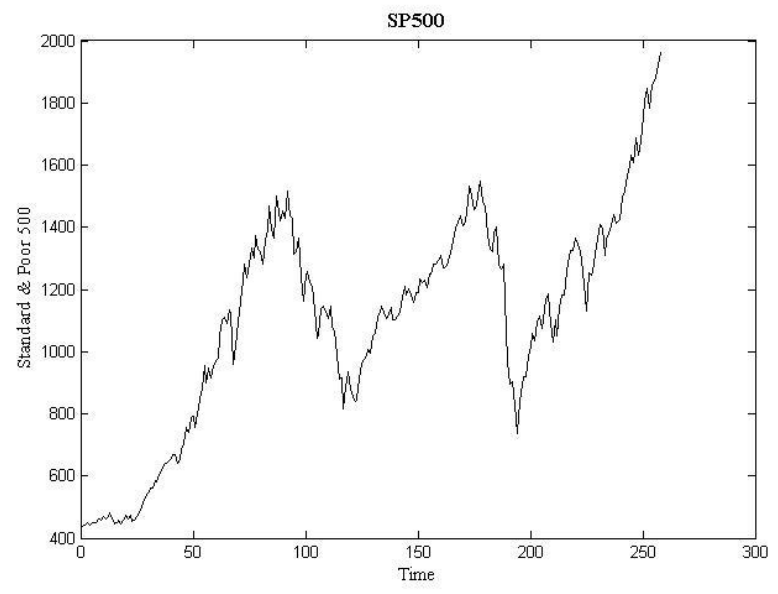

Figure 7 - Standard and Poor 500

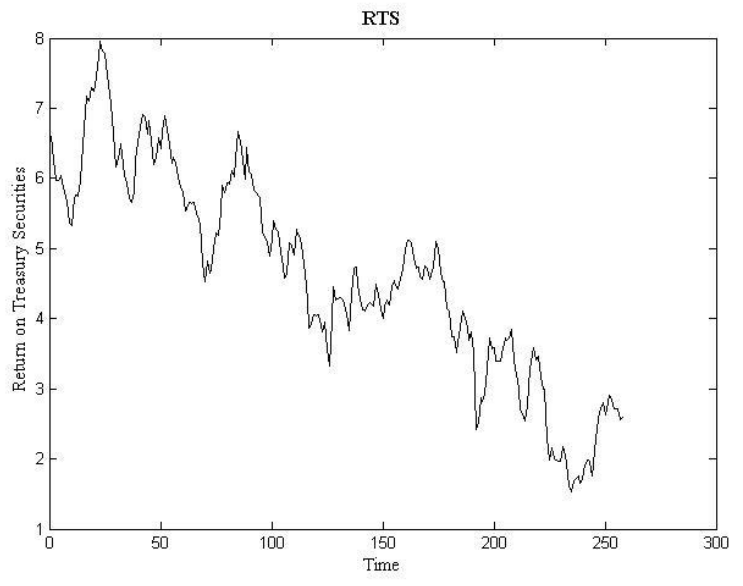

Figure 4 - Return on Treasury Securities

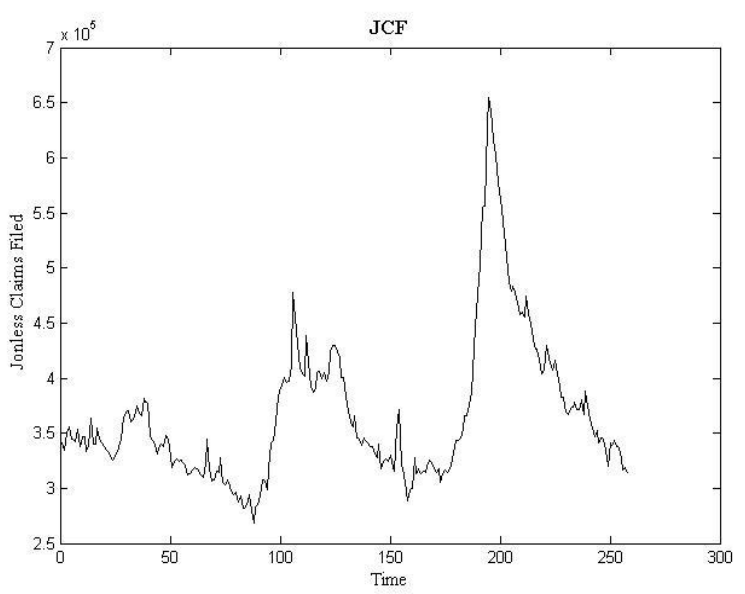

Figure 6 - Jobless Claims Filed

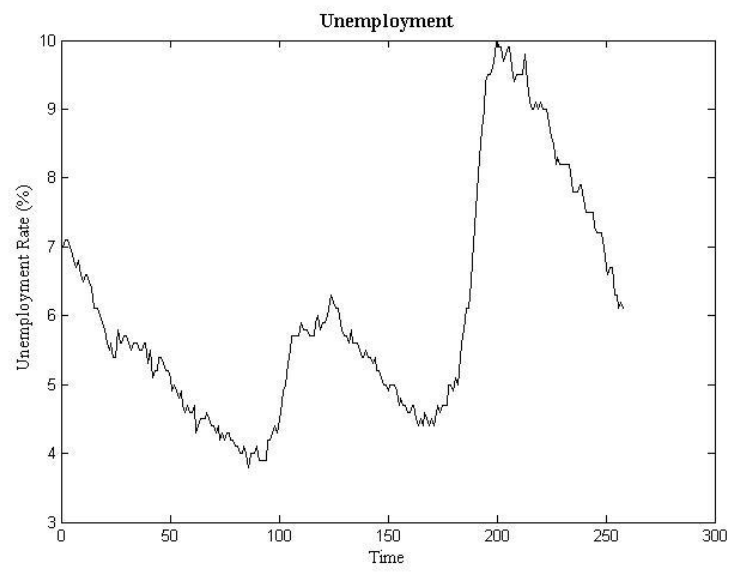

Figure 8 - US Unemployment Rate 


\subsection{Data Analysis}

Each of the five variables has a different scale. To have the same scale for all features, data should be normalized according to Equation 20 using the minimum and maximum value of that feature. Equation 21 was used to un-normalize the data after the analysis is done. These equations force all Scaled $\mathrm{X}(S X)$ to in a range between -1 and +1 .

$$
\begin{gathered}
S X=2 * \frac{X-\min (X)}{\max (X)-\min (X)}-1 ; \quad-1 \leq X_{N} \leq+1 \\
X=\frac{(S X+1)(\max (X)-\min (X))}{2}+\min (X)
\end{gathered}
$$




\section{Chapter 4: Results and Analysis}

The available data set was divided into two different sets: 1) Training set which is used to build the model; 2) Test data set which is not included in the training set and is used to validate the model. MLR, ANN and SVR were applied to the training data set using MATLAB 2014a. The percentages of dividing the data set into training and test are 80 and 20 which will be 207 and 51 data points, respectively. The approach to select 51 data points as test data set is to select every $5^{\text {th }}$ point starting from the first data point. The remaining 207 values are under training data set. All the models are built and tested based on the normalized data. The results are described in details in the following sections. To check if all the variables are significant or not, stepwise regression is used before implementing those three techniques.

\subsection{MLR Result}

Stepwise regression was applied to the training data set to test how significant each variable was in the model. The purpose of this section is trying to find the confidents in Equation 22.

$$
Y_{t}=\beta_{0}+\beta_{1} C P I_{t-2}+\beta_{2} R T S_{t-2}+\beta_{3} T N P_{t-2}+\beta_{4} J C F_{t-2}+\beta_{5} S P 500_{t-2}+\varepsilon_{t}
$$

The indexes of $t$ and $t-2$ all refer to the time of the forecasting. This method can be applied in MATLAB environment and starts with no variable in the model. The variable with the highest correlation enters the model and is tested to see if it should be in the model or it can be taken out due to being insignificant. The results are shown in the following steps and the coefficients of the models in each step are summarized in Tables 6 to 10.

\section{Step 1: JCF enters $-R^{2}=\mathbf{0 . 5 8 4}$}

Table 6 - Linear Regression Parameters when JCF is in model

\begin{tabular}{|c|c|c|c|c|c|c|}
\hline Variable & Coefficient & Std. Error & $\mathbf{t}$ & P-value & \multicolumn{2}{|c|}{ 95\% Confidence Interval } \\
\hline JCF & 1.179 & 0.069 & 16.980 & $5.88 \mathrm{E}-41$ & 1.043 & 1.316 \\
\hline Constant & 0.308 & 0.042 & 7.379 & $3.88 \mathrm{E}-12$ & 0.226 & 0.391 \\
\hline
\end{tabular}

Both p-values in the table are smaller than 0.05. Therefore, it is concluded that both the constant and JCF should stay in the model. 
Step 2: RTS enters $-\mathbf{R}^{2}=\mathbf{0 . 6 8 3}$

Table 7 - Linear Regression Parameter when RTS moves into the model

\begin{tabular}{|c|c|c|c|c|c|c|}
\hline Variable & Coefficient & Std. Error & $\mathbf{t}$ & P-value & \multicolumn{2}{|c|}{ 95\% Confidence Interval } \\
\hline RTS & -0.400 & 0.050 & 8.009 & $8.69 \mathrm{E}-14$ & -0.499 & -0.302 \\
\hline JCF & 0.944 & 0.067 & 14.005 & $1.13 \mathrm{E}-31$ & 0.812 & 1.077 \\
\hline Constant & 0.178 & 0.040 & 4.448 & $1.42 \mathrm{E}-05$ & 0.099 & 0.257 \\
\hline
\end{tabular}

All variables are significant in the model since all p-values are smaller than 0.05 .

Step 3: TNP enters $-\mathbf{R}^{2}=\mathbf{0 . 8 3 5}$

Table 8 - Linear Regression Parameter when TNP moves into the model

\begin{tabular}{|c|c|c|c|c|c|c|}
\hline Variable & Coefficient & Std. Error & $\mathbf{t}$ & P-value & \multicolumn{2}{|c|}{ 95\% Confidence Interval } \\
\hline RTS & -0.909 & 0.052 & -17.463 & $2.66 \mathrm{E}-42$ & -1.011 & -0.806 \\
\hline TNP & -0.578 & 0.042 & -13.612 & $2.07 \mathrm{E}-30$ & -0.662 & -0.495 \\
\hline JCF & 0.730 & 0.051 & 14.221 & $2.66 \mathrm{E}-32$ & 0.629 & 0.832 \\
\hline Constant & 0.240 & 0.029 & 8.174 & $3.18 \mathrm{E}-14$ & 0.182 & 0.298 \\
\hline
\end{tabular}

As p-values are smaller than the significance level 0.05, the model keeps all three variables.

Step 4: CPI enters $-R^{2}=0.958$

Table 9 - Linear Regression Parameter when CPI moves into the model

\begin{tabular}{|c|c|c|c|c|c|c|}
\hline Variable & Coefficient & Std. Error & $\mathbf{t}$ & P-value & \multicolumn{2}{|c|}{ 95\% Confidence Interval } \\
\hline CPI & 0.951 & 0.038 & 24.576 & $1.28 \mathrm{E}-62$ & 0.875 & 1.028 \\
\hline RTS & -0.142 & 0.041 & -3.494 & $5.85 \mathrm{E}-4$ & -0.222 & -0.062 \\
\hline TNP & -0.995 & 0.027 & -36.526 & $6.16 \mathrm{E}-91$ & -1.048 & -0.941 \\
\hline JCF & 0.661 & 0.026 & 25.481 & $5.13 \mathrm{E}-65$ & 0.609 & 0.711 \\
\hline Constant & 0.407 & 0.016 & 25.070 & $6.21 \mathrm{E}-64$ & 0.375 & 0.438 \\
\hline
\end{tabular}

All the small p-values ae showing that no variable should be taken out from the model. 
Step 5: SP500 moves in $-\mathbf{R}^{2}=\mathbf{0 . 9 6 1}$

Table 10 - Linear Regression Parameters when SP500 moves into the model

\begin{tabular}{|c|c|c|c|c|c|c|}
\hline Variable & Coefficient & Std. Error & $\mathbf{t}$ & P-value & \multicolumn{2}{|c|}{ 95\% Confidence Interval } \\
\hline CPI & 0.917 & 0.041 & 22.387 & $1.68 \mathrm{E}-56$ & 0.836 & 0.997 \\
\hline RTS & -0.125 & 0.041 & -3.025 & $2.80 \mathrm{E}-03$ & -0.206 & -0.043 \\
\hline TNP & -1.077 & 0.039 & -27.480 & $5.35 \mathrm{E}-70$ & -1.154 & -1.000 \\
\hline JCF & 0.730 & 0.035 & 20.836 & $4.11 \mathrm{E}-52$ & 0.661 & 0.800 \\
\hline SP500 & 0.153 & 0.047 & 3.145 & $1.79 \mathrm{E}-03$ & 0.058 & 0.248 \\
\hline Constant & 0.487 & 0.048 & 15.767 & $5.49 \mathrm{E}-37$ & 0.426 & 0.548 \\
\hline
\end{tabular}

Based on the stepwise regression results shown above, all variables are significant in the model and cannot be taken out because of the small p-values. Table 10 can also be represented as the result of MLR.

Table 11 shows the analysis of variance for the fitted model.

Table 11 - Analysis of Variance for Regression Model

\begin{tabular}{|c|c|c|c|c|c|}
\hline Source & DF & Sum of Squares & Mean Square & F-Value & P-value \\
\cline { 1 - 4 } Regression & 5 & 55.840 & 11.168 & 898.994 & $3.50 \mathrm{E}-139$ \\
\hline Error & 201 & 2.497 & 0.012 & \multicolumn{2}{|l}{} \\
\hline Total & 206 & 58.337 & \multicolumn{2}{|l}{} \\
\cline { 1 - 4 }
\end{tabular}

Since $F$ value is 898.994 and is much greater than $F_{0.05}(5,201)=2.26$, there is enough evidence to reject the null hypothesis shown in Equation 23. That means all variables are significant in the model.

$\left\{\begin{array}{c}H_{0}: \beta_{0}=\beta_{1}=\beta_{2}=\beta_{3}=\beta_{4}=\beta_{5}=0 \\ H_{1}: \beta_{i} \neq 0 \quad \forall i=0, \ldots, 5\end{array}\right.$

To forecast the unemployment rate for the test data set using MLR, Equation 24 can be used.

$$
\begin{aligned}
Y_{t}= & 0.487+0.917 C P I_{t-2}-0.125 R T S_{t-2}-1.077 T N P_{t-2}+0.730 J C F_{t-2} \\
& +0.153 S P 500_{t-2}+\varepsilon_{t}
\end{aligned}
$$

Figures 9 and 10 show the actual values of unemployment versus their prediction for the training set and test set using MLR, respectively. 


\section{MLR Result for Training Data}

12

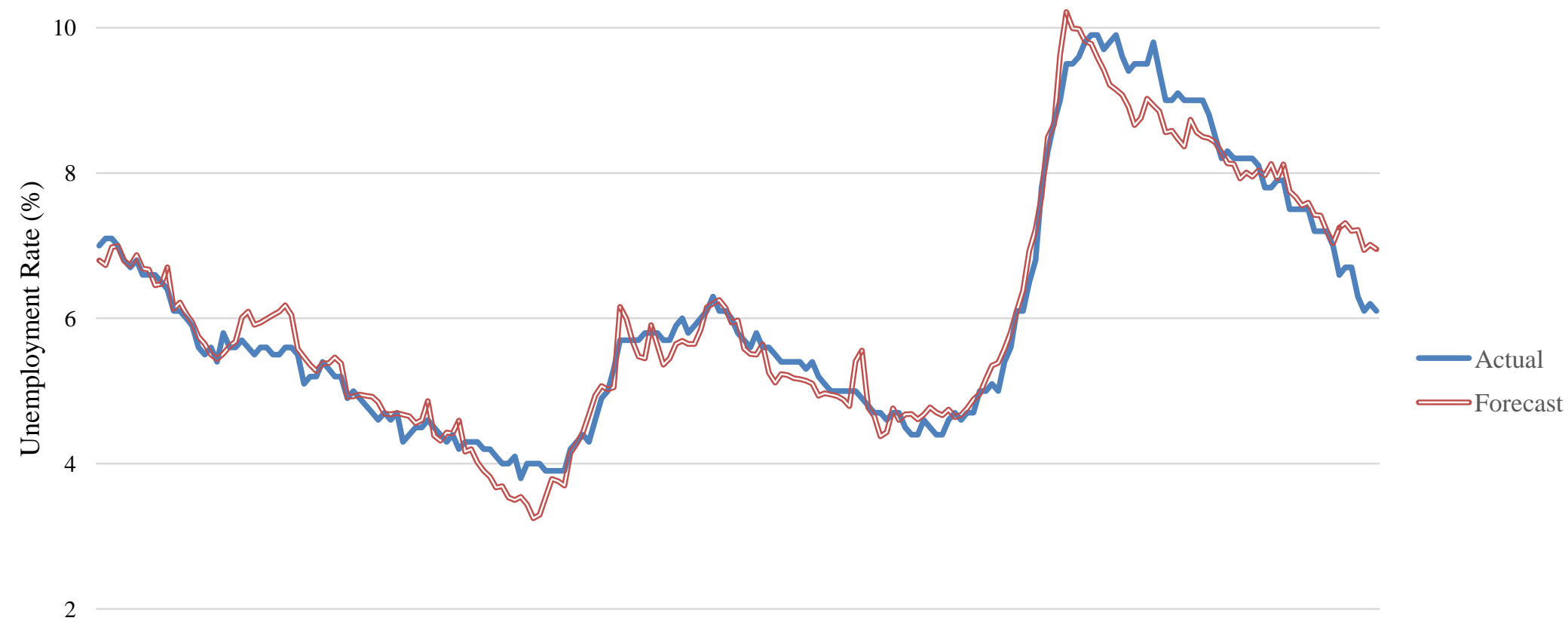

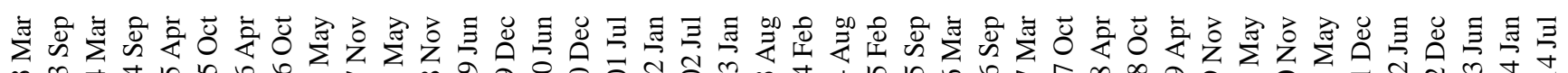

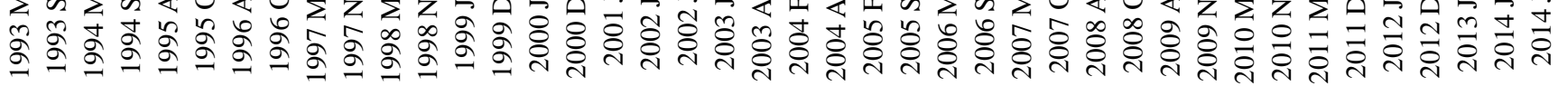




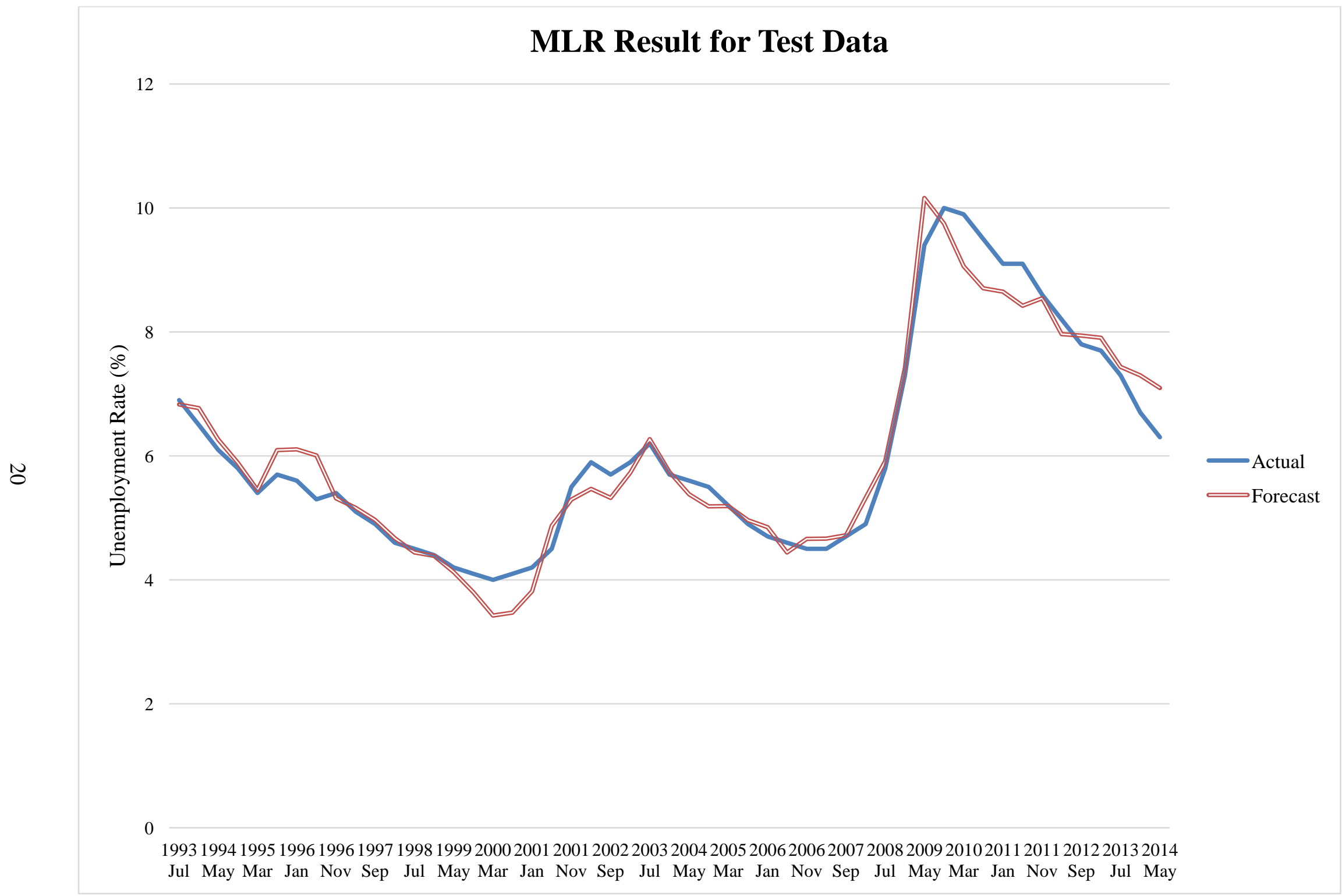

Figure 10 - MLR Test Result vs Actual Unemployment 


\subsubsection{Inference on MLR Results}

What was obtained so far using MLR was a point estimate for unemployment rate for each month. Another way to infer regarding predicted values is the interval estimate. An interval estimate can be defined by a minimum value and a maximum value between which the parameter is said to lie with a probability of $(1-\alpha) 100 \%$.

Table 12 below shows the prediction interval for each one of the 51 data points in the test data set. It was investigated if the actual values are within the range of the prediction interval for each month in the test set (all 51 data points).

Table 12 - Prediction Interval on MLR Results

\begin{tabular}{|c|c|c|c|c|}
\hline Min & Max & Actual Value & Forecast & In/Out \\
\hline 6.1 & 7.5 & 6.9 & 6.8 & I \\
\hline 6.1 & 7.5 & 6.5 & 6.8 & $\mathrm{I}$ \\
\hline 5.6 & 7.0 & 6.1 & 6.3 & $\mathrm{I}$ \\
\hline 5.2 & 6.6 & 5.8 & 5.9 & $\mathrm{I}$ \\
\hline 4.7 & 6.1 & 5.4 & 5.4 & $\mathrm{I}$ \\
\hline 5.4 & 6.8 & 5.7 & 6.1 & I \\
\hline 5.4 & 6.8 & 5.6 & 6.1 & I \\
\hline 5.3 & 6.7 & 5.3 & 6.0 & $\mathrm{I}$ \\
\hline 4.6 & 6.0 & 5.4 & 5.3 & $\mathrm{I}$ \\
\hline 4.5 & 5.9 & 5.1 & 5.2 & $\mathrm{I}$ \\
\hline 4.3 & 5.7 & 4.9 & 5.0 & $\mathrm{I}$ \\
\hline 4.0 & 5.4 & 4.6 & 4.7 & I \\
\hline 3.7 & 5.1 & 4.5 & 4.4 & I \\
\hline 3.7 & 5.1 & 4.4 & 4.4 & I \\
\hline 3.4 & 4.8 & 4.2 & 4.1 & $\mathrm{I}$ \\
\hline 3.1 & 4.5 & 4.1 & 3.8 & $\mathrm{I}$ \\
\hline 2.7 & 4.1 & 4 & 3.4 & $\mathrm{I}$ \\
\hline 2.8 & 4.2 & 4.1 & 3.5 & $\mathrm{I}$ \\
\hline 3.1 & 4.5 & 4.2 & 3.8 & I \\
\hline 4.2 & 5.6 & 4.5 & 4.9 & $\mathrm{I}$ \\
\hline 4.6 & 6.0 & 5.5 & 5.3 & I \\
\hline 4.8 & 6.2 & 5.9 & 5.5 & $\mathrm{I}$ \\
\hline 4.6 & 6.0 & 5.7 & 5.3 & I \\
\hline 5.0 & 6.4 & 5.9 & 5.7 & I \\
\hline 5.6 & 7.0 & 6.2 & 6.3 & I \\
\hline 5.0 & 6.4 & 5.7 & 5.7 & I \\
\hline
\end{tabular}




\begin{tabular}{|c|c|c|c|c|}
\hline \multicolumn{7}{|c|}{ Prediction Interval on MLR Results (Cont'd) } \\
\hline Min & Max & Actual Value & Forecast & In/Out \\
\hline 4.7 & 6.1 & 5.6 & 5.4 & I \\
\hline 4.5 & 5.9 & 5.5 & 5.2 & I \\
\hline 4.5 & 5.9 & 5.2 & 5.2 & I \\
\hline 4.3 & 5.7 & 4.9 & 5.0 & I \\
\hline 4.1 & 5.5 & 4.7 & 4.8 & I \\
\hline 3.7 & 5.1 & 4.6 & 4.4 & I \\
\hline 4.0 & 5.4 & 4.5 & 4.7 & I \\
\hline 4.0 & 5.4 & 4.5 & 4.7 & I \\
\hline 4.0 & 5.4 & 4.7 & 4.7 & I \\
\hline 4.6 & 6.0 & 4.9 & 5.3 & I \\
\hline 5.2 & 6.6 & 5.8 & 5.9 & I \\
\hline 6.7 & 8.1 & 7.3 & 7.4 & I \\
\hline 9.5 & 10.9 & 9.4 & 10.2 & O \\
\hline 9.1 & 10.5 & 10 & 9.8 & I \\
\hline 8.4 & 9.8 & 9.9 & 9.1 & O \\
\hline 8.0 & 9.4 & 9.5 & 8.7 & O \\
\hline 8.0 & 9.4 & 9.1 & 8.7 & I \\
\hline 7.7 & 9.1 & 9.1 & 8.4 & I \\
\hline 7.8 & 9.2 & 8.6 & 8.5 & I \\
\hline 7.3 & 8.7 & 8.2 & 8.0 & I \\
\hline 7.2 & 8.6 & 7.8 & 7.9 & I \\
\hline 7.2 & 8.6 & 7.7 & 7.9 & I \\
\hline 6.7 & 8.1 & 7.3 & 7.4 & I \\
\hline 6.6 & 8.0 & 6.7 & 7.3 & I \\
\hline 6.4 & 7.8 & 6.3 & 7.1 & O \\
\hline & & & & \\
\hline
\end{tabular}

Column 5 of Table 12 shows if the actual value of the unemployment rate falls Inside (I) or Outside $(\mathrm{O})$ of the prediction interval. Out of 51 data points, 4 unemployment rate fall outside of the boundaries which show a $92.1 \%$ accuracy in the prediction model using MLR. 


\subsection{ANN Result}

In this approach, same 207 data points as in MLR were considered to train the model. The remaining 51 data points were used to test the model. The sigmoid function was used in the training process.

The approach to test different learning rates was starting from 0.05 and increasing it by 0.05 every time. The model was run with the new learning rate and the results were analyzed. Learning rate of 0.05 gave the best results with the highest R-Squared value compared to other learning rates for this data set.

Also, one hidden layer and two-hidden layer models were tested with all possible number of neurons from 1 to 20 . The 1-hidden layer with 18 neuron model gave the smallest variance among all those tested. Figures 11 and 12 show the ANN results versus actual unemployment rates for the training data set and test data set, respectively. 


\section{ANN Result for Training Data}

12

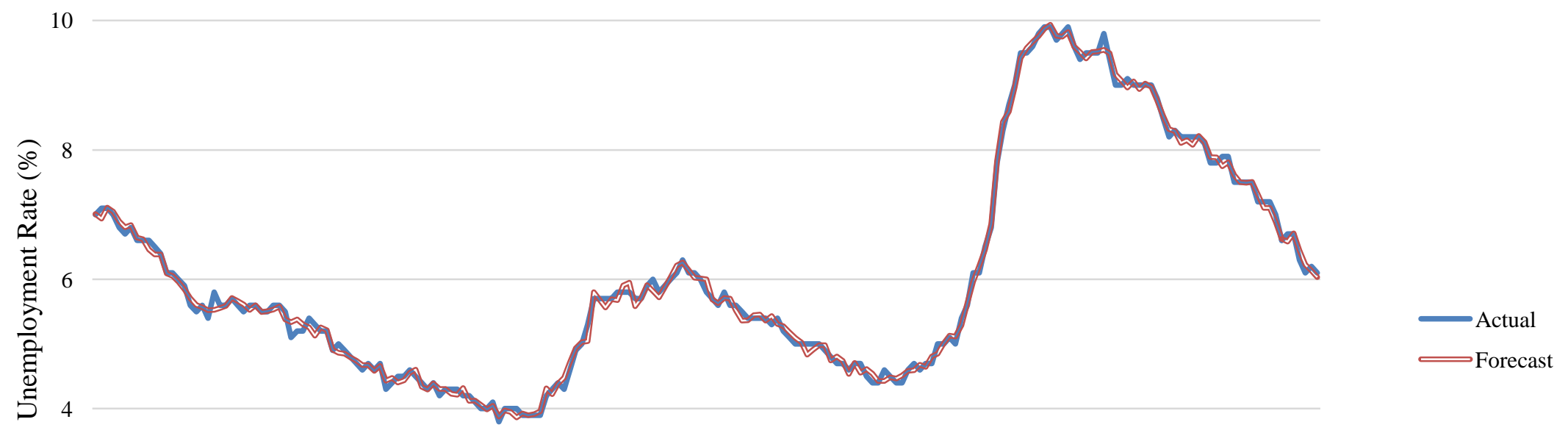

2

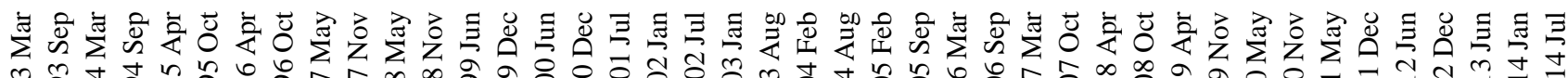

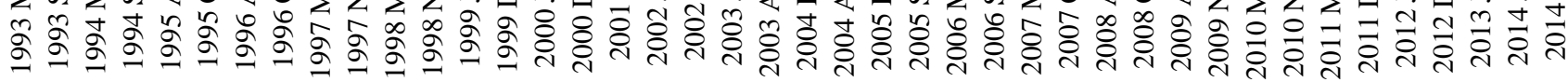




\section{ANN Result for Test Data}

12

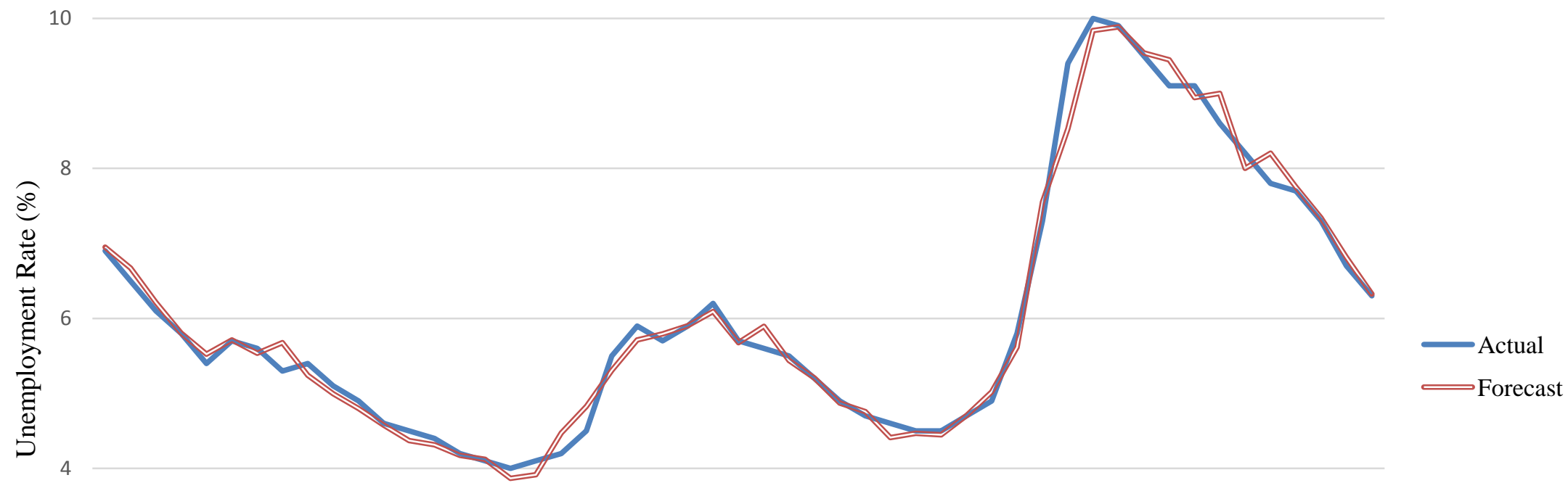

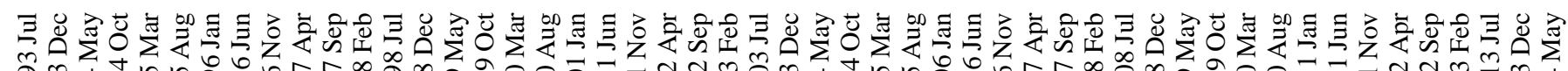

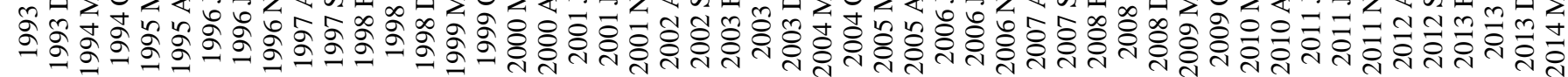

Figure 12 - ANN Test Result vs Actual Unemployment 


\subsubsection{Inference on ANN Result}

The prediction intervals on ANN results show that $98 \%$ of the prediction intervals include the actual value of unemployment rate for the test data. The boundaries and comparisons are shown in Table 13.

Table 13 - Prediction Intervals on ANN Results

\begin{tabular}{|c|c|c|c|c|}
\hline Min & Max & Actual Value & Forecast & In/Out \\
\hline 6.2 & 7.6 & 6.9 & 6.9 & I \\
\hline 6 & 7.4 & 6.5 & 6.7 & $\mathrm{I}$ \\
\hline 5.5 & 6.9 & 6.1 & 6.2 & I \\
\hline 5.1 & 6.5 & 5.8 & 5.8 & I \\
\hline 4.8 & 6.2 & 5.4 & 5.5 & I \\
\hline 5 & 6.4 & 5.7 & 5.7 & $\mathrm{I}$ \\
\hline 4.8 & 6.2 & 5.6 & 5.5 & $\mathrm{I}$ \\
\hline 5 & 6.4 & 5.3 & 5.7 & $\mathrm{I}$ \\
\hline 4.5 & 5.9 & 5.4 & 5.2 & I \\
\hline 4.3 & 5.7 & 5.1 & 5.0 & $\mathrm{I}$ \\
\hline 4.1 & 5.5 & 4.9 & 4.8 & $\mathrm{I}$ \\
\hline 3.9 & 5.3 & 4.6 & 4.6 & I \\
\hline 3.7 & 5.1 & 4.5 & 4.4 & $\mathrm{I}$ \\
\hline 3.6 & 5 & 4.4 & 4.3 & $\mathrm{I}$ \\
\hline 3.5 & 4.9 & 4.2 & 4.2 & I \\
\hline 3.4 & 4.8 & 4.1 & 4.1 & I \\
\hline 3.2 & 4.6 & 4 & 3.9 & $\mathrm{I}$ \\
\hline 3.2 & 4.6 & 4.1 & 3.9 & $\mathrm{I}$ \\
\hline 3.8 & 5.2 & 4.2 & 4.5 & $\mathrm{I}$ \\
\hline 4.1 & 5.5 & 4.5 & 4.8 & I \\
\hline 4.6 & 6 & 5.5 & 5.3 & I \\
\hline 5 & 6.4 & 5.9 & 5.7 & $\mathrm{I}$ \\
\hline 5.1 & 6.5 & 5.7 & 5.8 & $\mathrm{I}$ \\
\hline 5.2 & 6.6 & 5.9 & 5.9 & $\mathrm{I}$ \\
\hline 5.4 & 6.8 & 6.2 & 6.1 & $\mathrm{I}$ \\
\hline 5 & 6.4 & 5.7 & 5.7 & $\mathrm{I}$ \\
\hline 5.2 & 6.6 & 5.6 & 5.9 & I \\
\hline 4.7 & 6.1 & 5.5 & 5.4 & I \\
\hline 4.5 & 5.9 & 5.2 & 5.2 & $\mathrm{I}$ \\
\hline 4.2 & 5.6 & 4.9 & 4.9 & I \\
\hline 4.1 & 5.5 & 4.7 & 4.8 & $\mathrm{I}$ \\
\hline 3.7 & 5.1 & 4.6 & 4.4 & I \\
\hline
\end{tabular}




\begin{tabular}{|c|c|c|c|c|}
\hline \multicolumn{7}{|c|}{ Prediction Interval on ANN Results (Cont'd) } \\
\hline Min & Max & Actual Value & Forecast & In/Out \\
\hline 3.8 & 5.2 & 4.5 & 4.5 & I \\
\hline 3.7 & 5.1 & 4.5 & 4.4 & I \\
\hline 4 & 5.4 & 4.7 & 4.7 & I \\
\hline 4.3 & 5.7 & 4.9 & 5.0 & I \\
\hline 4.9 & 6.3 & 5.8 & 5.6 & I \\
\hline 6.9 & 8.3 & 7.3 & 7.6 & I \\
\hline 7.8 & 9.2 & 9.4 & 8.5 & O \\
\hline 9.1 & 10.5 & 10 & 9.8 & I \\
\hline 9.2 & 10.6 & 9.9 & 9.9 & I \\
\hline 8.8 & 10.2 & 9.5 & 9.5 & I \\
\hline 8.7 & 10.1 & 9.1 & 9.4 & I \\
\hline 8.2 & 9.6 & 9.1 & 8.9 & I \\
\hline 8.3 & 9.7 & 8.6 & 9.0 & I \\
\hline 7.3 & 8.7 & 8.2 & 8.0 & I \\
\hline 7.5 & 8.9 & 7.8 & 8.2 & I \\
\hline 7.1 & 8.5 & 7.7 & 7.8 & I \\
\hline 6.6 & 8 & 7.3 & 7.3 & I \\
\hline 6.1 & 7.5 & 6.7 & 6.8 & I \\
\hline 5.6 & 7 & 6.3 & 6.3 & I \\
\hline
\end{tabular}




\subsection{SVR Result}

The SVR method used the same training and test data sets. This method was run 100 times and the results of the best among them were selected. Getting the same results was the reason why additional runs were not carried out.

The type of the kernel function used in SVR method was Radial Basis Function (RBF). The parameters that gave the better model are shown in Table 14 below.

Table 14 - SVR Model Parameters

\begin{tabular}{|c|c|}
\hline Parameter & value \\
\hline$\varepsilon$ & 0.003 \\
\hline $\mathrm{C}$ & 247 \\
\hline$\sigma$ & 0.15 \\
\hline
\end{tabular}

The result of the training and test processes in comparison to the actual unemployment rate are shown in Figures 13 and 14, respectively. 


\section{SVR Result for Training Data}

12

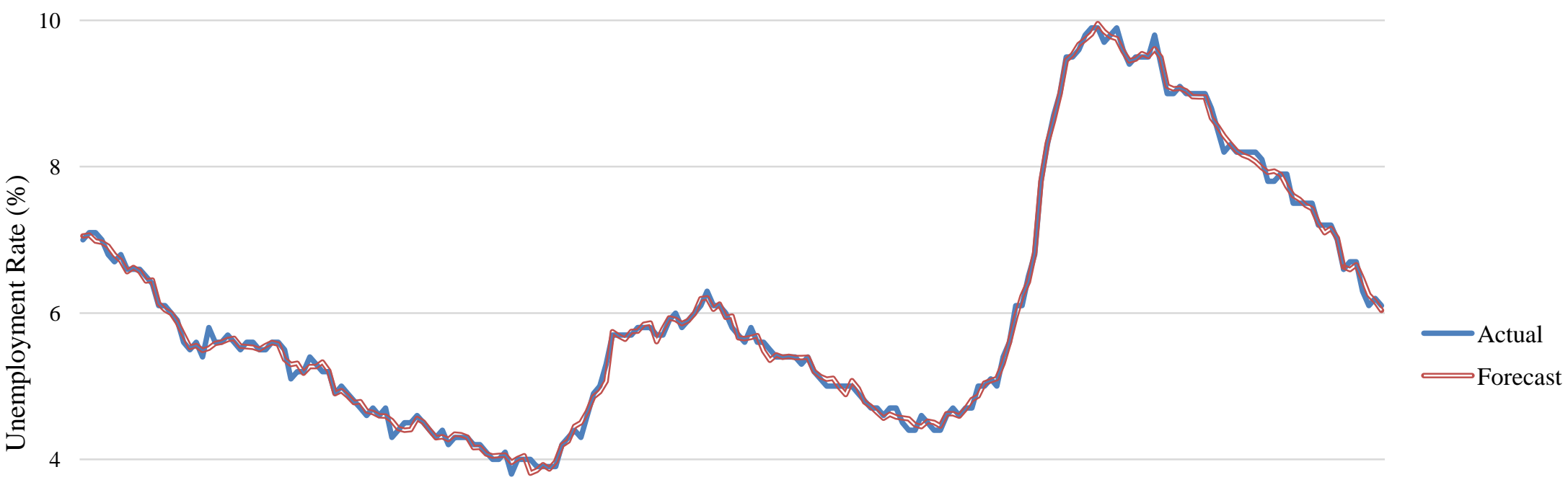

2

0

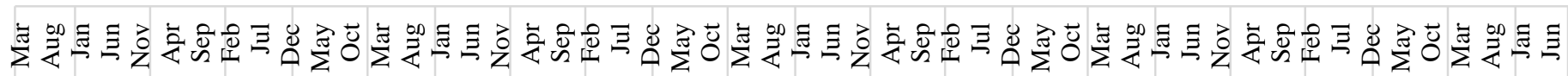

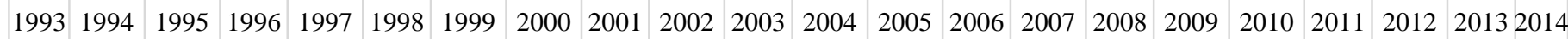




\section{SVR Result for Test Data}

12

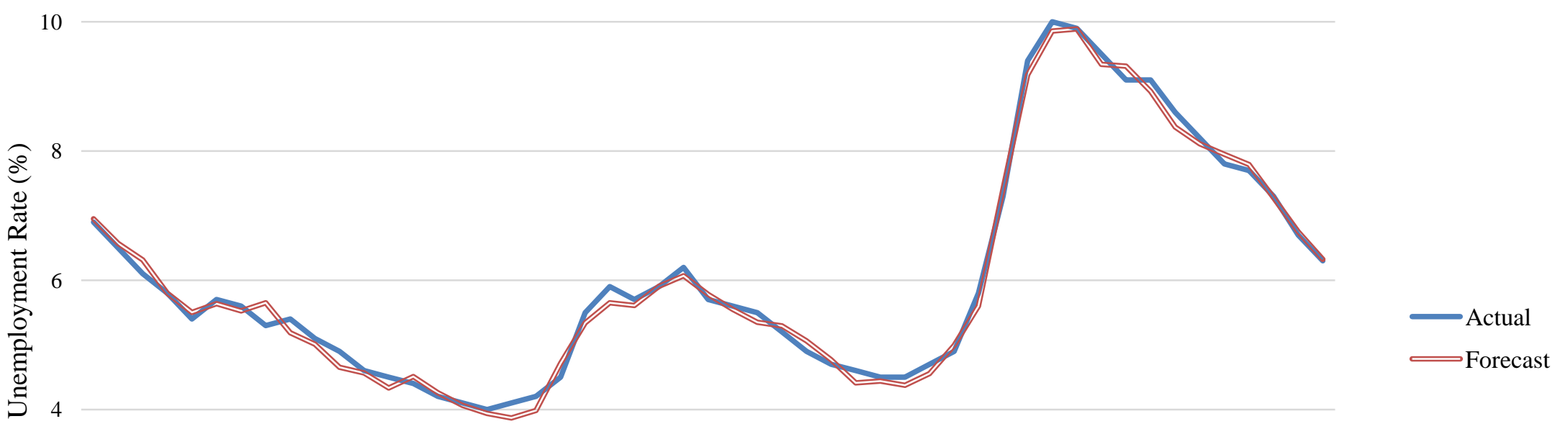

2

0 Jul May Mar Jan Nov Sep Jul May Mar Jan Nov Sep Jul May Mar Jan Nov Sep Jul May Mar Jan Nov Sep Jul May

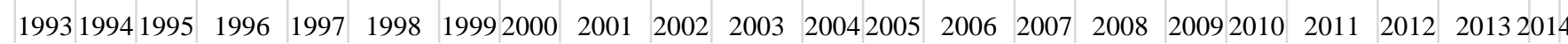




\subsubsection{Inference on SVR Results}

Using SVR predicted results, the following prediction intervals were obtained that are shown in Table 15. These prediction intervals all include the actual values on unemployment rate which shows a $100 \%$ accuracy of SVR prediction model on this data set.

Table 15 - Prediction Interval on SVR Results

\begin{tabular}{|c|c|c|c|c|}
\hline Min & Max & Actual Value & Forecast & In/Out \\
\hline 6.2 & 7.6 & 6.9 & 6.9 & $\mathrm{I}$ \\
\hline 5.9 & 7.3 & 6.5 & 6.6 & $\mathrm{I}$ \\
\hline 5.6 & 7 & 6.1 & 6.3 & $\mathrm{I}$ \\
\hline 5.1 & 6.5 & 5.8 & 5.8 & $\mathrm{I}$ \\
\hline 4.8 & 6.2 & 5.4 & 5.5 & $\mathrm{I}$ \\
\hline 4.9 & 6.3 & 5.7 & 5.6 & $\mathrm{I}$ \\
\hline 4.8 & 6.2 & 5.6 & 5.5 & $\mathrm{I}$ \\
\hline 5 & 6.4 & 5.3 & 5.7 & $\mathrm{I}$ \\
\hline 4.5 & 5.9 & 5.4 & 5.2 & $\mathrm{I}$ \\
\hline 4.3 & 5.7 & 5.1 & 5.0 & $\mathrm{I}$ \\
\hline 4 & 5.4 & 4.9 & 4.7 & $\mathrm{I}$ \\
\hline 3.9 & 5.3 & 4.6 & 4.6 & $\mathrm{I}$ \\
\hline 3.6 & 5 & 4.5 & 4.3 & $\mathrm{I}$ \\
\hline 3.8 & 5.2 & 4.4 & 4.5 & $\mathrm{I}$ \\
\hline 3.6 & 5 & 4.2 & 4.3 & $\mathrm{I}$ \\
\hline 3.4 & 4.8 & 4.1 & 4.1 & $\mathrm{I}$ \\
\hline 3.2 & 4.6 & 4 & 3.9 & $\mathrm{I}$ \\
\hline 3.2 & 4.6 & 4.1 & 3.9 & $\mathrm{I}$ \\
\hline 3.3 & 4.7 & 4.2 & 4.0 & $\mathrm{I}$ \\
\hline 4 & 5.4 & 4.5 & 4.7 & $\mathrm{I}$ \\
\hline 4.6 & 6 & 5.5 & 5.3 & $\mathrm{I}$ \\
\hline 5 & 6.4 & 5.9 & 5.7 & $\mathrm{I}$ \\
\hline 4.9 & 6.3 & 5.7 & 5.6 & $\mathrm{I}$ \\
\hline 5.2 & 6.6 & 5.9 & 5.9 & $\mathrm{I}$ \\
\hline 5.4 & 6.8 & 6.2 & 6.1 & $\mathrm{I}$ \\
\hline 5.1 & 6.5 & 5.7 & 5.8 & $\mathrm{I}$ \\
\hline 4.9 & 6.3 & 5.6 & 5.6 & $\mathrm{I}$ \\
\hline 4.6 & 6 & 5.5 & 5.3 & $\mathrm{I}$ \\
\hline 4.6 & 6 & 5.2 & 5.3 & $\mathrm{I}$ \\
\hline 4.4 & 5.8 & 4.9 & 5.1 & $\mathrm{I}$ \\
\hline 4.1 & 5.5 & 4.7 & 4.8 & $\mathrm{I}$ \\
\hline 3.7 & 5.1 & 4.6 & 4.4 & $\mathrm{I}$ \\
\hline & & & & \\
\hline
\end{tabular}


Prediction Interval on SVR Results (Cont'd)

\begin{tabular}{|c|c|c|c|c|}
\hline Min & Max & Actual Value & Forecast & In/Out \\
\hline 3.7 & 5.1 & 4.5 & 4.4 & $\mathrm{I}$ \\
\hline 3.7 & 5.1 & 4.5 & 4.4 & $\mathrm{I}$ \\
\hline 3.9 & 5.3 & 4.7 & 4.6 & $\mathrm{I}$ \\
\hline 4.3 & 5.7 & 4.9 & 5.0 & $\mathrm{I}$ \\
\hline 4.9 & 6.3 & 5.8 & 5.6 & $\mathrm{I}$ \\
\hline 6.7 & 8.1 & 7.3 & 7.4 & $\mathrm{I}$ \\
\hline 8.5 & 9.9 & 9.4 & 9.2 & $\mathrm{I}$ \\
\hline 9.2 & 10.6 & 10 & 9.9 & $\mathrm{I}$ \\
\hline 9.2 & 10.6 & 9.9 & 9.9 & $\mathrm{I}$ \\
\hline 8.6 & 10 & 9.5 & 9.3 & $\mathrm{I}$ \\
\hline 8.6 & 10 & 9.1 & 9.3 & $\mathrm{I}$ \\
\hline 8.2 & 9.6 & 9.1 & 8.9 & $\mathrm{I}$ \\
\hline 7.7 & 9.1 & 8.6 & 8.4 & $\mathrm{I}$ \\
\hline 7.4 & 8.8 & 8.2 & 8.1 & $\mathrm{I}$ \\
\hline 7.2 & 8.6 & 7.8 & 7.9 & $\mathrm{I}$ \\
\hline 7.1 & 8.5 & 7.7 & 7.8 & $\mathrm{I}$ \\
\hline 6.6 & 8 & 7.3 & 7.3 & $\mathrm{I}$ \\
\hline 6.1 & 7.5 & 6.7 & 6.8 & $\mathrm{I}$ \\
\hline 5.6 & 7 & 6.3 & 6.3 & $\mathrm{I}$ \\
\hline
\end{tabular}

Table 16 shows the prediction intervals for all three methods for easier comparison.

Table 16 - Prediction Intervals Summary

\begin{tabular}{|c|c|c|c|c|c|}
\hline Year & Month & MLR PI & ANN PI & SVR PI & Actual \\
\hline 1993 & Jul & $(6.1,7.5)$ & $(6.2,7.6)$ & $(6.2,7.6)$ & 6.9 \\
\hline 1993 & Dec & $(6.1,7.5)$ & $(6,7.4)$ & $(5.9,7.3)$ & 6.5 \\
\hline 1994 & May & $(5.6,7)$ & $(5.5,6.9)$ & $(5.6,7)$ & 6.1 \\
\hline 1994 & Oct & $(5.2,6.6)$ & $(5.1,6.5)$ & $(5.1,6.5)$ & 5.8 \\
\hline 1995 & Mar & $(4.7,6.1)$ & $(4.8,6.2)$ & $(4.8,6.2)$ & 5.4 \\
\hline 1995 & Aug & $(5.4,6.8)$ & $(5,6.4)$ & $(4.9,6.3)$ & 5.7 \\
\hline 1996 & Jan & $(5.4,6.8)$ & $(4.8,6.2)$ & $(4.8,6.2)$ & 5.6 \\
\hline 1996 & Jun & $(5.3,6.7)$ & $(5,6.4)$ & $(5,6.4)$ & 5.3 \\
\hline 1996 & Nov & $(4.6,6)$ & $(4.5,5.9)$ & $(4.5,5.9)$ & 5.4 \\
\hline 1997 & Apr & $(4.5,5.9)$ & $(4.3,5.7)$ & $(4.3,5.7)$ & 5.1 \\
\hline 1997 & Sep & $(4.3,5.7)$ & $(4.1,5.5)$ & $(4,5.4)$ & 4.9 \\
\hline 1998 & Feb & $(4,5.4)$ & $(3.9,5.3)$ & $(3.9,5.3)$ & 4.6 \\
\hline 1998 & Jul & $(3.7,5.1)$ & $(3.7,5.1)$ & $(3.6,5)$ & 4.5 \\
\hline 1998 & Dec & $(3.7,5.1)$ & $(3.6,5)$ & $(3.8,5.2)$ & 4.4 \\
\hline
\end{tabular}


Prediction Intervals Summary (Cont'd)

\begin{tabular}{|c|c|c|c|c|c|}
\hline Year & Month & MLR PI & ANN PI & SVR PI & Actual \\
\hline 1999 & May & $(3.4,4.8)$ & $(3.5,4.9)$ & $(3.6,5)$ & 4.2 \\
\hline 1999 & Oct & $(3.1,4.5)$ & $(3.4,4.8)$ & $(3.4,4.8)$ & 4.1 \\
\hline 2000 & Mar & $(2.7,4.1)$ & $(3.2,4.6)$ & $(3.2,4.6)$ & 4 \\
\hline 2000 & Aug & $(2.8,4.2)$ & $(3.2,4.6)$ & $(3.2,4.6)$ & 4.1 \\
\hline 2001 & Jan & $(3.1,4.5)$ & $(3.8,5.2)$ & $(3.3,4.7)$ & 4.2 \\
\hline 2001 & Jun & $(4.2,5.6)$ & $(4.1,5.5)$ & $(4,5.4)$ & 4.5 \\
\hline 2001 & Nov & $(4.6,6)$ & $(4.6,6)$ & $(4.6,6)$ & 5.5 \\
\hline 2002 & Apr & $(4.8,6.2)$ & $(5,6.4)$ & $(5,6.4)$ & 5.9 \\
\hline 2002 & Sep & $(4.6,6)$ & $(5.1,6.5)$ & $(4.9,6.3)$ & 5.7 \\
\hline 2003 & Feb & $(5,6.4)$ & $(5.2,6.6)$ & $(5.2,6.6)$ & 5.9 \\
\hline 2003 & Jul & $(5.6,7)$ & $(5.4,6.8)$ & $(5.4,6.8)$ & 6.2 \\
\hline 2003 & Dec & $(5,6.4)$ & $(5,6.4)$ & $(5.1,6.5)$ & 5.7 \\
\hline 2004 & May & $(4.7,6.1)$ & $(5.2,6.6)$ & $(4.9,6.3)$ & 5.6 \\
\hline 2004 & Oct & $(4.5,5.9)$ & $(4.7,6.1)$ & $(4.6,6)$ & 5.5 \\
\hline 2005 & Mar & $(4.5,5.9)$ & $(4.5,5.9)$ & $(4.6,6)$ & 5.2 \\
\hline 2005 & Aug & $(4.3,5.7)$ & $(4.2,5.6)$ & $(4.4,5.8)$ & 4.9 \\
\hline 2006 & Jan & $(4.1,5.5)$ & $(4.1,5.5)$ & $(4.1,5.5)$ & 4.7 \\
\hline 2006 & Jun & $(3.7,5.1)$ & $(3.7,5.1)$ & $(3.7,5.1)$ & 4.6 \\
\hline 2006 & Nov & $(4,5.4)$ & $(3.8,5.2)$ & $(3.7,5.1)$ & 4.5 \\
\hline 2007 & Apr & $(4,5.4)$ & $(3.7,5.1)$ & $(3.7,5.1)$ & 4.5 \\
\hline 2007 & Sep & $(4,5.4)$ & $(4,5.4)$ & $(3.9,5.3)$ & 4.7 \\
\hline 2008 & Feb & $(4.6,6)$ & $(4.3,5.7)$ & $(4.3,5.7)$ & 4.9 \\
\hline 2008 & Jul & $(5.2,6.6)$ & $(4.9,6.3)$ & $(4.9,6.3)$ & 5.8 \\
\hline 2008 & Dec & $(6.7,8.1)$ & $(6.9,8.3)$ & $(6.7,8.1)$ & 7.3 \\
\hline 2009 & May & $(9.5,10.9)$ & $(7.8,9.2)$ & $(8.5,9.9)$ & 9.4 \\
\hline 2009 & Oct & $(9.1,10.5)$ & $(9.1,10.5)$ & $(9.2,10.6)$ & 10 \\
\hline 2010 & Mar & $(8.4,9.8)$ & $(9.2,10.6)$ & $(9.2,10.6)$ & 9.9 \\
\hline 2010 & Aug & $(8,9.4)$ & $(8.8,10.2)$ & $(8.6,10)$ & 9.5 \\
\hline 2011 & Jan & $(8,9.4)$ & $(8.7,10.1)$ & $(8.6,10)$ & 9.1 \\
\hline 2011 & Jun & $(7.7,9.1)$ & $(8.2,9.6)$ & $(8.2,9.6)$ & 9.1 \\
\hline 2011 & Nov & $(7.8,9.2)$ & $(8.3,9.7)$ & $(7.7,9.1)$ & 8.6 \\
\hline 2012 & Apr & $(7.3,8.7)$ & $(7.3,8.7)$ & $(7.4,8.8)$ & 8.2 \\
\hline 2012 & Sep & $(7.2,8.6)$ & $(7.5,8.9)$ & $(7.2,8.6)$ & 7.8 \\
\hline 2013 & Feb & $(7.2,8.6)$ & $(7.1,8.5)$ & $(7.1,8.5)$ & 7.7 \\
\hline 2013 & Jul & $(6.7,8.1)$ & $(6.6,8)$ & $(6.6,8)$ & 7.3 \\
\hline 2013 & Dec & $(6.6,8)$ & $(6.1,7.5)$ & $(6.1,7.5)$ & 6.7 \\
\hline 2014 & May & $(6.4,7.8)$ & $(5.6,7)$ & $(5.6,7)$ & 6.3 \\
\hline \multicolumn{2}{|c|}{ Accuracy \% } & $92.1 \%$ & $98 \%$ & $100 \%$ & \\
\hline
\end{tabular}




\subsection{R-Squared and MSE Values}

The accuracy of the models was determined based on both the adjusted R-squared and Mean Squared Errors (MSE). Table 17 below shows the adjusted- $\mathrm{R}^{2}$ and MSE values for test data set for all three techniques. It shows that SVR outperforms other two techniques on this data set with respect to both R-squared and MSE.

Table 17 - Comparative Results

\begin{tabular}{|c|c|c|}
\hline Method & Adjusted R-squared & MSE \\
\hline MLR & 0.951 & 0.048 \\
\hline ANN & 0.985 & 0.015 \\
\hline SVR & $\mathbf{0 . 9 9 2 *}$ & $\mathbf{0 . 0 0 7} *$ \\
\hline
\end{tabular}




\section{Chapter 5: Conclusion}

It has always been crucial for governments to predict and try to decrease the unemployment rate. Several methods and techniques have been used to forecast unemployment rate in the literature. However, none of them used economic factors to forecast the unemployment rate. In this study, a model was developed such that the unemployment rate can be predicted using the value of those economic factors in the previous periods for the first time. Five different factors were used for each month to forecast the unemployment rate for two months ahead. The available data set was divided into two different sets to build and test the model. The validation process was done inside the training step. MLR, ANN and SVR techniques were used to predict the unemployment rates and the results were compared. It was shown that Support Vector Regression gave the better results on this data set. All the results for all techniques and the actual values are shown in Figure 15 for the test data set for easier comparison.

Also, prediction intervals for all 51 points were calculated to check how many of them included the actual unemployment rate. The results summarized in Table 16 showed that MLR includes $92.1 \%$ of the actual values, ANN includes $98 \%$ and SVR includes $100 \%$ of the actual values on this data set. Percentage of accuracy is a ratio of the number of prediction intervals that include the actual value over the total which is 51 .

The results of future forecast for September and October 2014 is shown in Table 18 for all three methods.

Table 18 - Future Forecast based on the Trained Models

\begin{tabular}{|l|c|c|c|c|}
\hline Date & MLR & ANN & SVR & Actual \\
\hline Sep-14 & 6.71 & 6.12 & 5.96 & 5.90 \\
\hline Oct-14 & 6.62 & 5.76 & 5.88 & 5.80 \\
\hline
\end{tabular}




\section{Prediction Result}

12

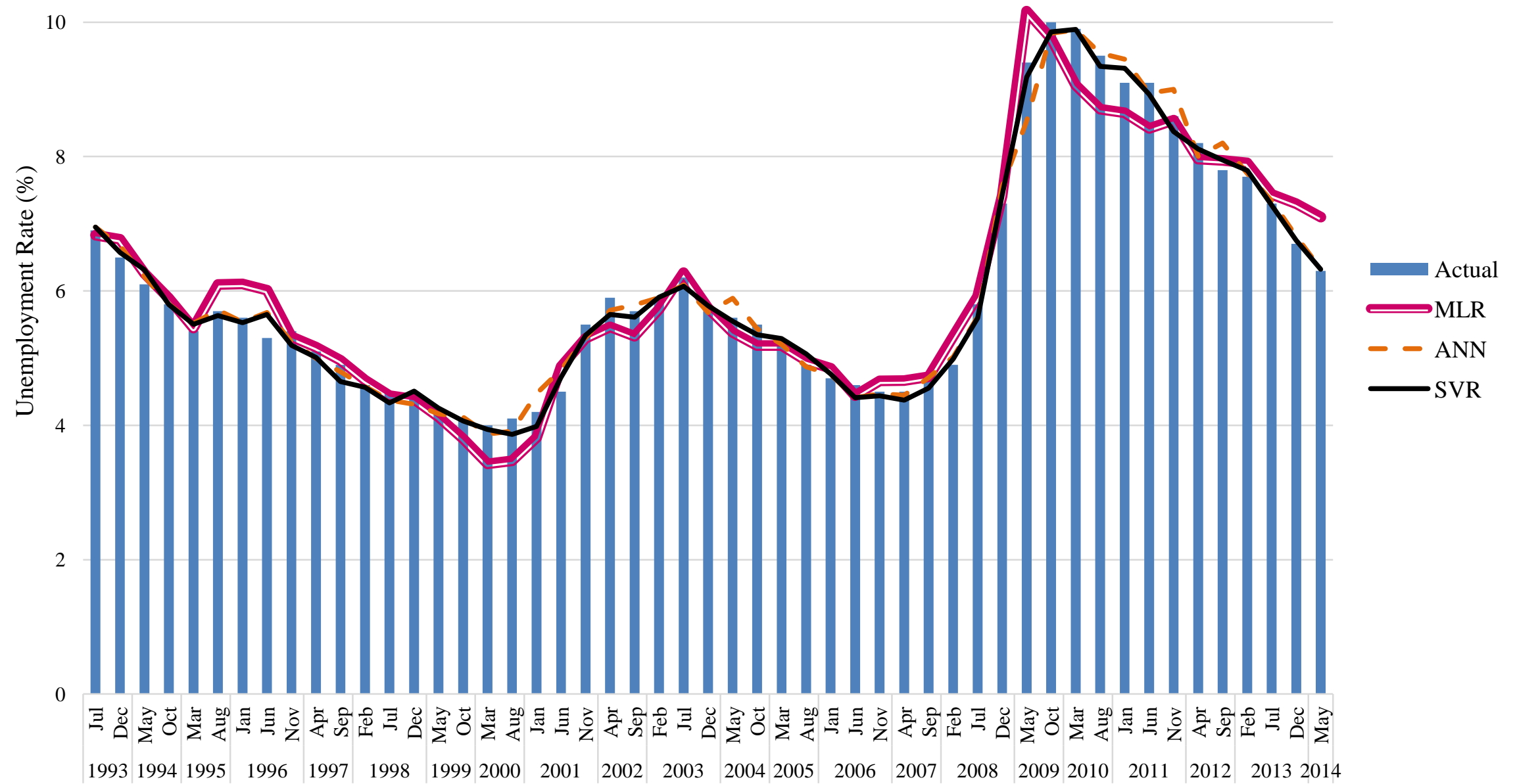

Figure 15 - Test Results for all Techniques vs. Actual Unemployment 


\subsection{Future Work}

Unemployment rate considered as an important factor in countries economy and depends on different factors. This study explored five different economic factors to predict unemployment rate. Considering more factors for future work studies may improve the prediction quality. All the methods of this study were applying deterministic data where in reality data is more stochastic rather than deterministic. It could be a good contribution if fuzzy data were considered for unemployment estimation because of fluctuation in the nature of the data. There are a lot of different methods available including heuristic techniques that have great performance depending on the situation. Those methods can also be explored for future studies of unemployment rate.

Using quadratic terms for regression model may improve the results. Considering the value of unemployment rates for historical data can also be included as another factor to forecast future unemployment rate. There are several other regression techniques that can be tried on this data set to improve the results such as quantile regression. 


\section{References}

1. Altissimo, F., \& Violante, G. L. (2001). The nonlinear dynamics of output and unemployment in the US. Journal of Applied Econometrics, 16(4), 461-486.

2. Baily, Martin Neil \& Okun, Arthur M. (1965) The Battle Against Unemployment and Inflation: Problems of the Modern Economy. New York: W.W. Norton \& Co.; ISBN 0393-95055-7 (1983; 3rd revised edition).

3. Barnichon, R., Nekarda, C. J., HATZIUS, J., STEHN, S. J., \& PETRONGOLO, B. (2012). The Ins and Outs of Forecasting Unemployment: Using Labor Force Flows to Forecast the Labor Market [with Comments and Discussion]. Brookings Papers on Economic Activity, 83-131.

4. Caner, M., \& Hansen, B. E. (2004). Instrumental variable estimation of a threshold model. Econometric Theory, 20(05), 813-843.

5. Duda, R. O., Hart, P. E., \& Stork, D. G. (2012). Pattern classification. John Wiley \& Sons.

6. Hair, J. F., Tatham, R. L., Anderson, R. E., \& Black, W. (2006). Multivariate data analysis (Vol. 6). Upper Saddle River, NJ: Pearson Prentice Hall.

7. Kennedy, P. (1992). A Guide to Econometrics. Oxford: Blackwell

8. Kissock, J.K., Haberl. J. and Claridge, D.E., 2003. Inverse Modeling Toolkit (1050RP): Numerical Algorithms. ASHRAE Transactions, 109(2).

9. Marquaridt, D. W. (1970). Generalized inverses, ridge regression, biased linear estimation, and nonlinear estimation. Technometrics, 12(3), 591-612.

10. McCulloch, W. S., \& Pitts, W. (1943). A logical calculus of the ideas immanent in nervous activity. The bulletin of mathematical biophysics, 5(4), 115-133.

11. Milas, C., \& Rothman, P. (2008). Out-of-sample forecasting of unemployment rates with pooled STVECM forecasts. International Journal of Forecasting,24(1), 101-121.

12. Montgomery, A. L., Zarnowitz, V., Tsay, R. S., \& Tiao, G. C. (1998). Forecasting the US unemployment rate. Journal of the American Statistical Association, 93(442), 478-493.

13. Neter, J., Wasserman, W., \& Kutner, M. H. (1989). Applied linear regression models.

14. Olmedo, E. (2014). Forecasting Spanish Unemployment Using Near Neighbor and Neural Net Techniques. Computational Economics, 43(2), 183-197.

15. Pan, Y., \& Jackson, R. T. (2008). Ethnic difference in the relationship between acute inflammation and serum ferritin in US adult males. Epidemiology and infection, 136(03), 421-431.

16. Proietti, T. (2003). Forecasting the US unemployment rate. Computational statistics \& data analysis, 42(3), 451-476. 
17. Rogerson, P. (2001). Statistical methods for geography. Sage.

18. Rothman, P. (1998). Forecasting asymmetric unemployment rates. Review of Economics and Statistics, 80(1), 164-168.

19. Rumelhart, D. E., Hinton, G. E., \& Williams, R. J. (1988). Learning representations by back-propagating errors. Cognitive modeling.

20. Vapnik, V. (2000). The nature of statistical learning theory. springer.

21. Voineagu, V., Pisica, S., \& Caragea, N. (2012). Forecasting Monthly Unemployment by Econometric Smoothing Techniques. Economic computation and economic cybernetics studies and research, 46(3), 255-267.

22. Weigend, A. S., \& Gershenfeld, N. A. (1994). Time series prediction: forecasting the future and understanding the past. URL http://adsabs. harvard. edu/cgi-bin/nphbib_query. 


\section{Appendix A: Input Data}

To forecast the unemployment rate in February 1993, the values of those five variables in January 1993 are used.

\begin{tabular}{c|l} 
Variable & Definition \\
\hline CPI & $\begin{array}{l}\text { Average monthly change in the price of goods/services paid by urban consumers } \\
\text { between any two time periods }\end{array}$ \\
RTS & $\begin{array}{l}\text { Correction for equivalent maturity to find an index using the average yield of } \\
\text { different returned treasury securities maturing at various periods } \\
\text { TNP }\end{array}$ \\
JCF & $\begin{array}{l}\text { Number of jobs added to an economy or lost in it } \\
\text { benefits of jobless claims filed by those who are willing to receive state jobless } \\
\text { An economic indicator that shows the whole U.S. stock market by keeping track of } \\
\text { the 500 most commonly held stock on NYSE }\end{array}$ \\
SP500
\end{tabular}

\begin{tabular}{cccccc} 
Date & CPI & RTS & TNP & JCF & SP500 \\
\hline Jan-93 & 142.800 & 6.60 & 109805 & 341200 & 438.78 \\
Feb-93 & 143.100 & 6.26 & 110047 & 334813 & 443.38 \\
Mar-93 & 143.300 & 5.98 & 109998 & 350313 & 451.67 \\
Apr-93 & 143.800 & 5.97 & 110306 & 355688 & 440.19 \\
May-93 & 144.200 & 6.04 & 110573 & 345050 & 450.19 \\
Jun-93 & 144.300 & 5.96 & 110754 & 344188 & 450.53 \\
Jul-93 & 144.500 & 5.81 & 111053 & 341800 & 448.13 \\
Aug-93 & 144.800 & 5.68 & 111212 & 353438 & 463.56 \\
Sep-93 & 145.000 & 5.36 & 111451 & 337750 & 458.93 \\
Oct-93 & 145.600 & 5.33 & 111737 & 346950 & 467.83 \\
Nov-93 & 146.000 & 5.72 & 111999 & 346438 & 461.79 \\
Dec-93 & 146.300 & 5.77 & 112311 & 332875 & 466.45 \\
Jan-94 & 146.300 & 5.75 & 112583 & 338750 & 481.61 \\
Feb-94 & 146.700 & 5.97 & 112783 & 363250 & 467.14 \\
Mar-94 & 147.100 & 6.48 & 113248 & 340000 & 445.77 \\
Apr-94 & 147.200 & 6.97 & 113597 & 340150 & 450.91 \\
May-94 & 147.500 & 7.18 & 113931 & 354625 & 456.5 \\
Jun-94 & 147.900 & 7.10 & 114247 & 345313 & 444.27 \\
Jul-94 & 148.400 & 7.30 & 114624 & 341600 & 458.26 \\
Aug-94 & 149.000 & 7.24 & 114902 & 337813 & 475.49 \\
Sep-94 & 149.300 & 7.46 & 115253 & 334125 & 462.71 \\
Oct-94 & 149.400 & 7.74 & 115468 & 331900 & 472.35 \\
& & & 41 & &
\end{tabular}




\begin{tabular}{cccccc} 
Date & CPI & RTS & TNP & JCF & SP500 \\
\hline Nov-94 & 149.800 & 7.96 & 115887 & 329250 & 453.69 \\
Dec-94 & 150.100 & 7.81 & 116162 & 325850 & 459.27 \\
Jan-95 & 150.500 & 7.78 & 116487 & 330125 & 470.42 \\
Feb-95 & 150.900 & 7.47 & 116691 & 333188 & 487.39 \\
Mar-95 & 151.200 & 7.20 & 116913 & 341063 & 500.71 \\
Apr-95 & 151.800 & 7.06 & 117075 & 344250 & 514.71 \\
May-95 & 152.100 & 6.63 & 117059 & 364375 & 533.4 \\
Jun-95 & 152.400 & 6.17 & 117294 & 369063 & 544.75 \\
Jul-95 & 152.600 & 6.28 & 117395 & 370150 & 562.06 \\
Aug-95 & 152.900 & 6.49 & 117644 & 360500 & 561.88 \\
Sep-95 & 153.100 & 6.20 & 117885 & 362350 & 584.41 \\
Oct-95 & 153.500 & 6.04 & 118041 & 366188 & 581.5 \\
Nov-95 & 153.700 & 5.93 & 118189 & 374938 & 605.37 \\
Dec-95 & 153.900 & 5.71 & 118321 & 368350 & 615.93 \\
Jan-96 & 154.700 & 5.65 & 118303 & 366125 & 636.02 \\
Feb-96 & 155.000 & 5.81 & 118735 & 382000 & 640.43 \\
Mar-96 & 155.500 & 6.27 & 119001 & 378050 & 645.5 \\
Apr-96 & 156.100 & 6.51 & 119165 & 377563 & 654.17 \\
May-96 & 156.400 & 6.74 & 119485 & 347688 & 669.12 \\
Jun-96 & 156.700 & 6.91 & 119774 & 344000 & 670.63 \\
Jul-96 & 157.000 & 6.87 & 120029 & 339688 & 639.95 \\
Aug-96 & 157.200 & 6.64 & 120202 & 331550 & 651.99 \\
Sep-96 & 157.700 & 6.83 & 120427 & 337188 & 687.33 \\
Oct-96 & 158.200 & 6.53 & 120677 & 340625 & 705.27 \\
Nov-96 & 158.700 & 6.20 & 120976 & 337800 & 757.02 \\
Dec-96 & 159.100 & 6.30 & 121146 & 347813 & 740.74 \\
Jan-97 & 159.400 & 6.58 & 121382 & 344563 & 786.16 \\
Feb-97 & 159.700 & 6.42 & 121684 & 328688 & 790.82 \\
Mar-97 & 159.800 & 6.69 & 122000 & 318550 & 757.12 \\
Apr-97 & 159.900 & 6.89 & 122293 & 323938 & 801.34 \\
May-97 & 159.900 & 6.71 & 122551 & 326600 & 848.28 \\
Jun-97 & 160.200 & 6.49 & 122818 & 324500 & 885.14 \\
Jul-97 & 160.400 & 6.22 & 123131 & 325563 & 954.31 \\
Aug-97 & 160.800 & 6.30 & 123092 & 322950 & 899.47 \\
Sep-97 & 161.200 & 6.21 & 123604 & 321125 & 947.28 \\
Oct-97 & 161.500 & 6.03 & 123945 & 312500 & 914.62 \\
Nov-97 & 161.700 & 5.88 & 124251 & 312700 & 955.4 \\
Dec-97 & 161.800 & 5.81 & 124554 & 316063 & 970.43 \\
& 162.000 & 5.54 & 124830 & 318800 & 980.28 \\
Jan-98 & 162.000 & 5.57 & 125026 & 317375 & 1049.34
\end{tabular}




\begin{tabular}{|c|c|c|c|c|c|}
\hline Date & CPI & RTS & TNP & JCF & SP500 \\
\hline Mar-98 & 162.000 & 5.65 & 125177 & 316813 & 1101.75 \\
\hline Apr-98 & 162.200 & 5.64 & 125456 & 312625 & 1111.75 \\
\hline May-98 & 162.600 & 5.65 & 125862 & 309800 & 1090.82 \\
\hline Jun-98 & 162.800 & 5.50 & 126080 & 322500 & 1133.84 \\
\hline Jul-98 & 163.200 & 5.46 & 126204 & 345000 & 1120.67 \\
\hline Aug-98 & 163.400 & 5.34 & 126551 & 318250 & 957.28 \\
\hline Sep-98 & 163.500 & 4.81 & 126775 & 306875 & 1017.01 \\
\hline Oct-98 & 163.900 & 4.53 & 126971 & 307400 & 1098.67 \\
\hline Nov-98 & 164.100 & 4.83 & 127254 & 315250 & 1163.63 \\
\hline Dec-98 & 164.400 & 4.65 & 127601 & 313813 & 1229.23 \\
\hline Jan-99 & 164.700 & 4.72 & 127726 & 327750 & 1279.64 \\
\hline Feb-99 & 164.700 & 5.00 & 128137 & 305063 & 1238.33 \\
\hline Mar-99 & 164.800 & 5.23 & 128244 & 303188 & 1286.37 \\
\hline Apr-99 & 165.900 & 5.18 & 128619 & 308000 & 1335.18 \\
\hline May-99 & 166.000 & 5.54 & 128831 & 302300 & 1301.84 \\
\hline Jun-99 & 166.000 & 5.90 & 129092 & 297688 & 1372.71 \\
\hline Jul-99 & 166.700 & 5.79 & 129411 & 294300 & 1328.72 \\
\hline Aug-99 & 167.100 & 5.94 & 129578 & 296188 & 1320.41 \\
\hline Sep-99 & 167.800 & 5.92 & 129791 & 287813 & 1282.71 \\
\hline Oct-99 & 168.100 & 6.11 & 130192 & 293350 & 1362.93 \\
\hline Nov-99 & 168.400 & 6.03 & 130483 & 282063 & 1388.91 \\
\hline Dec-99 & 168.800 & 6.28 & 130778 & 281438 & 1469.25 \\
\hline Jan-00 & 169.300 & 6.66 & 131008 & 285300 & 1394.46 \\
\hline Feb-00 & 170.000 & 6.52 & 131138 & 294125 & 1366.42 \\
\hline Mar-00 & 171.000 & 6.26 & 131606 & 279625 & 1498.58 \\
\hline Apr-00 & 170.900 & 5.99 & 131893 & 269000 & 1452.43 \\
\hline May-00 & 171.200 & 6.44 & 132119 & 282500 & 1420.6 \\
\hline Jun-00 & 172.200 & 6.10 & 132074 & 285750 & 1454.6 \\
\hline Jul-00 & 172.700 & 6.05 & 132251 & 293150 & 1430.83 \\
\hline Aug-00 & 172.700 & 5.83 & 132237 & 307125 & 1517.68 \\
\hline Sep-00 & 173.600 & 5.80 & 132371 & 306400 & 1436.51 \\
\hline Oct-00 & 173.900 & 5.74 & 132357 & 299188 & 1429.4 \\
\hline Nov-00 & 174.200 & 5.72 & 132582 & 318125 & 1314.95 \\
\hline Dec-00 & 174.600 & 5.24 & 132724 & 341450 & 1320.28 \\
\hline 1-Jan & 175.600 & 5.16 & 132694 & 343188 & 1366.01 \\
\hline $1-\mathrm{Feb}$ & 176.000 & 5.10 & 132766 & 361938 & 1239.94 \\
\hline 1-Mar & 176.100 & 4.89 & 132741 & 383500 & 1160.33 \\
\hline 1-Apr & 176.400 & 5.14 & 132460 & 391250 & 1249.46 \\
\hline 1-May & 177.300 & 5.39 & 132422 & 394000 & 1255.82 \\
\hline 1-Jun & 177.700 & 5.28 & 132293 & 400750 & 1224.38 \\
\hline 1-Jul & 177.400 & 5.24 & 132178 & 396313 & 1211.23 \\
\hline
\end{tabular}




\begin{tabular}{|c|c|c|c|c|c|}
\hline Date & CPI & RTS & TNP & JCF & SP500 \\
\hline 1-Aug & 177.400 & 4.97 & 132020 & 396875 & 1133.58 \\
\hline 1-Sep & 178.100 & 4.73 & 131778 & 411550 & 1040.94 \\
\hline 1-Oct & 177.600 & 4.57 & 131454 & 478063 & 1059.78 \\
\hline 1-Nov & 177.500 & 4.65 & 131160 & 455750 & 1139.45 \\
\hline 1-Dec & 177.400 & 5.09 & 130989 & 430750 & 1148.08 \\
\hline 2-Jan & 177.700 & 5.04 & 130847 & 409375 & 1130.2 \\
\hline $2-\mathrm{Feb}$ & 178.000 & 4.91 & 130714 & 404313 & 1106.73 \\
\hline 2-Mar & 178.500 & 5.28 & 130695 & 401700 & 1147.39 \\
\hline 2-Apr & 179.300 & 5.21 & 130615 & 438188 & 1076.92 \\
\hline 2-May & 179.500 & 5.16 & 130607 & 413500 & 1067.14 \\
\hline 2-Jun & 179.600 & 4.93 & 130664 & 392900 & 989.82 \\
\hline 2-Jul & 180.000 & 4.65 & 130579 & 387125 & 911.62 \\
\hline 2-Aug & 180.500 & 4.26 & 130564 & 390350 & 916.07 \\
\hline 2-Sep & 180.800 & 3.87 & 130504 & 405500 & 815.28 \\
\hline 2-Oct & 181.200 & 3.94 & 130629 & 406563 & 885.76 \\
\hline 2-Nov & 181.500 & 4.05 & 130639 & 400000 & 936.31 \\
\hline 2-Dec & 181.800 & 4.03 & 130481 & 405250 & 879.82 \\
\hline 3-Jan & 182.600 & 4.05 & 130575 & 397563 & 855.7 \\
\hline $3-\mathrm{Feb}$ & 183.600 & 3.90 & 130422 & 405375 & 841.15 \\
\hline 3-Mar & 183.900 & 3.81 & 130212 & 424050 & 848.18 \\
\hline 3-Apr & 183.200 & 3.96 & 130167 & 429625 & 916.92 \\
\hline 3-May & 182.900 & 3.57 & 130156 & 429500 & 963.59 \\
\hline 3-Jun & 183.100 & 3.33 & 130166 & 423750 & 974.5 \\
\hline 3-Jul & 183.700 & 3.98 & 130189 & 418500 & 990.31 \\
\hline 3-Aug & 184.500 & 4.45 & 130148 & 400750 & 1008.01 \\
\hline 3-Sep & 185.100 & 4.27 & 130250 & 401000 & 995.97 \\
\hline 3-Oct & 184.900 & 4.29 & 130446 & 383625 & 1050.71 \\
\hline 3-Nov & 185.000 & 4.30 & 130462 & 369900 & 1058.2 \\
\hline 3-Dec & 185.500 & 4.27 & 130586 & 360188 & 1111.92 \\
\hline 4-Jan & 186.300 & 4.15 & 130747 & 356300 & 1131.13 \\
\hline 4-Feb & 186.700 & 4.08 & 130791 & 365625 & 1144.94 \\
\hline 4-Mar & 187.100 & 3.83 & 131123 & 346250 & 1126.21 \\
\hline 4-Apr & 187.400 & 4.35 & 131372 & 345125 & 1107.3 \\
\hline 4-May & 188.200 & 4.72 & 131679 & 339000 & 1120.68 \\
\hline 4-Jun & 188.900 & 4.73 & 131753 & 346063 & 1140.84 \\
\hline 4-Jul & 189.100 & 4.50 & 131785 & 343850 & 1101.72 \\
\hline 4-Aug & 189.200 & 4.28 & 131917 & 340750 & 1104.24 \\
\hline 4-Sep & 189.800 & 4.13 & 132079 & 337750 & 1114.58 \\
\hline 4-Oct & 190.800 & 4.10 & 132425 & 337350 & 1130.2 \\
\hline 4-Nov & 191.700 & 4.19 & 132490 & 330688 & 1173.82 \\
\hline 4-Dec & 191.700 & 4.23 & 132619 & 328250 & 1211.92 \\
\hline
\end{tabular}




\begin{tabular}{|c|c|c|c|c|c|}
\hline Date & CPI & RTS & TNP & JCF & SP500 \\
\hline 5-Jan & 191.600 & 4.22 & 132753 & 340250 & 1181.27 \\
\hline $5-\mathrm{Feb}$ & 192.400 & 4.17 & 132992 & 317813 & 1203.6 \\
\hline 5-Mar & 193.100 & 4.50 & 133126 & 324375 & 1180.59 \\
\hline 5-Apr & 193.700 & 4.34 & 133489 & 326450 & 1156.85 \\
\hline 5-May & 193.600 & 4.14 & 133664 & 324625 & 1191.5 \\
\hline 5-Jun & 193.700 & 4.00 & 133909 & 330313 & 1191.33 \\
\hline 5-Jul & 194.900 & 4.18 & 134282 & 324450 & 1234.18 \\
\hline 5-Aug & 196.100 & 4.26 & 134478 & 316000 & 1220.33 \\
\hline 5-Sep & 198.800 & 4.20 & 134545 & 355000 & 1228.81 \\
\hline 5-Oct & 199.100 & 4.46 & 134629 & 371450 & 1207.01 \\
\hline 5-Nov & 198.100 & 4.54 & 134966 & 321750 & 1249.48 \\
\hline 5-Dec & 198.100 & 4.47 & 135125 & 318000 & 1248.29 \\
\hline 6-Jan & 199.300 & 4.42 & 135402 & 304938 & 1280.08 \\
\hline 6-Feb & 199.400 & 4.57 & 135717 & 288750 & 1280.66 \\
\hline 6-Mar & 199.700 & 4.72 & 135997 & 298313 & 1294.87 \\
\hline 6-Apr & 200.700 & 4.99 & 136179 & 299600 & 1310.61 \\
\hline 6-May & 201.300 & 5.11 & 136202 & 327438 & 1270.09 \\
\hline 6-Jun & 201.800 & 5.11 & 136279 & 313125 & 1270.2 \\
\hline 6-Jul & 202.900 & 5.09 & 136486 & 317700 & 1276.66 \\
\hline 6-Aug & 203.800 & 4.88 & 136670 & 313063 & 1303.82 \\
\hline 6-Sep & 202.800 & 4.72 & 136827 & 315850 & 1335.85 \\
\hline 6-Oct & 201.900 & 4.73 & 136829 & 313875 & 1377.94 \\
\hline 6-Nov & 202.000 & 4.60 & 137039 & 320313 & 1400.63 \\
\hline 6-Dec & 203.100 & 4.56 & 137210 & 325150 & 1418.3 \\
\hline 7-Jan & 203.437 & 4.76 & 137448 & 323313 & 1438.24 \\
\hline 7-Feb & 204.226 & 4.72 & 137536 & 319250 & 1406.82 \\
\hline 7-Mar & 205.288 & 4.56 & 137724 & 314900 & 1420.86 \\
\hline 7-Apr & 205.904 & 4.69 & 137802 & 318000 & 1482.37 \\
\hline 7-May & 206.755 & 4.75 & 137946 & 305813 & 1530.62 \\
\hline 7-Jun & 207.234 & 5.10 & 138017 & 312700 & 1503.35 \\
\hline 7-Jul & 207.603 & 5.00 & 137984 & 316063 & 1455.27 \\
\hline 7-Aug & 207.667 & 4.67 & 137968 & 314188 & 1473.99 \\
\hline 7-Sep & 208.547 & 4.52 & 138053 & 317250 & 1526.75 \\
\hline 7-Oct & 209.190 & 4.53 & 138135 & 320813 & 1549.38 \\
\hline 7-Nov & 210.834 & 4.15 & 138253 & 331875 & 1481.14 \\
\hline 7-Dec & 211.445 & 4.10 & 138350 & 343850 & 1468.36 \\
\hline 8-Jan & 212.174 & 3.74 & 138365 & 343625 & 1378.55 \\
\hline 8-Feb & 212.687 & 3.74 & 138279 & 345375 & 1330.63 \\
\hline 8-Mar & 213.448 & 3.51 & 138199 & 354300 & 1322.7 \\
\hline 8-Apr & 213.942 & 3.68 & 137985 & 365313 & 1385.59 \\
\hline 8-May & 215.208 & 3.88 & 137803 & 365900 & 1400.38 \\
\hline
\end{tabular}




\begin{tabular}{|c|c|c|c|c|c|}
\hline Date & CPI & RTS & TNP & JCF & SP500 \\
\hline 8-Jun & 217.463 & 4.10 & 137631 & 375438 & 1280 \\
\hline 8-Jul & 219.016 & 4.01 & 137421 & 387063 & 1267.38 \\
\hline 8-Aug & 218.690 & 3.89 & 137162 & 427950 & 1282.83 \\
\hline 8-Sep & 218.877 & 3.69 & 136710 & 447000 & 1166.36 \\
\hline 8-Oct & 216.995 & 3.81 & 136236 & 475688 & 968.75 \\
\hline 8-Nov & 213.153 & 3.53 & 135471 & 503300 & 896.24 \\
\hline 8-Dec & 211.398 & 2.42 & 134774 & 554500 & 903.25 \\
\hline 9-Jan & 211.933 & 2.52 & 133976 & 556450 & 825.88 \\
\hline 9-Feb & 212.705 & 2.87 & 133275 & 628500 & 735.09 \\
\hline 9-Mar & 212.495 & 2.82 & 132449 & 654875 & 797.87 \\
\hline 9-Apr & 212.709 & 2.93 & 131765 & 642188 & 872.81 \\
\hline 9-May & 213.022 & 3.29 & 131411 & 616200 & 919.14 \\
\hline 9-Jun & 214.790 & 3.72 & 130944 & 602000 & 919.32 \\
\hline 9-Jul & 214.726 & 3.56 & 130617 & 576875 & 987.48 \\
\hline 9-Aug & 215.445 & 3.59 & 130401 & 561850 & 1020.62 \\
\hline 9-Sep & 215.861 & 3.40 & 130174 & 553625 & 1057.08 \\
\hline 9-Oct & 216.509 & 3.39 & 129976 & 531350 & 1036.19 \\
\hline 9-Nov & 217.234 & 3.40 & 129970 & 510313 & 1095.63 \\
\hline 9-Dec & 217.347 & 3.59 & 129687 & 487750 & 1115.1 \\
\hline 10-Jan & 217.466 & 3.73 & 129705 & 478500 & 1073.87 \\
\hline $10-\mathrm{Feb}$ & 217.251 & 3.69 & 129655 & 483625 & 1104.49 \\
\hline 10-Mar & 217.305 & 3.73 & 129811 & 477438 & 1169.43 \\
\hline 10-Apr & 217.376 & 3.85 & 130062 & 468438 & 1186.69 \\
\hline 10-May & 217.299 & 3.42 & 130578 & 457900 & 1089.41 \\
\hline 10-Jun & 217.285 & 3.20 & 130456 & 460125 & 1030.71 \\
\hline 10-Jul & 217.677 & 3.01 & 130395 & 455450 & 1101.6 \\
\hline 10-Aug & 218.012 & 2.70 & 130353 & 474875 & 1049.33 \\
\hline 10-Sep & 218.281 & 2.65 & 130296 & 459063 & 1141.2 \\
\hline 10-Oct & 219.024 & 2.54 & 130537 & 449900 & 1183.26 \\
\hline 10-Nov & 219.544 & 2.76 & 130674 & 435563 & 1180.55 \\
\hline 10-Dec & 220.437 & 3.29 & 130745 & 426563 & 1257.64 \\
\hline 11-Jan & 221.082 & 3.39 & 130815 & 426250 & 1286.12 \\
\hline 11-Feb & 221.816 & 3.58 & 130983 & 415938 & 1327.22 \\
\hline 11-Mar & 222.955 & 3.41 & 131195 & 403938 & 1325.83 \\
\hline 11-Apr & 224.056 & 3.46 & 131517 & 407850 & 1363.61 \\
\hline 11-May & 224.918 & 3.17 & 131619 & 429688 & 1345.2 \\
\hline 11-Jun & 224.990 & 3.00 & 131836 & 418125 & 1320.64 \\
\hline 11-Jul & 225.553 & 3.00 & 131942 & 413900 & 1292.28 \\
\hline 11-Aug & 226.149 & 2.30 & 132064 & 407625 & 1218.89 \\
\hline 11-Sep & 226.674 & 1.98 & 132285 & 415938 & 1131.42 \\
\hline 11-Oct & 226.761 & 2.15 & 132468 & 404200 & 1253.3 \\
\hline
\end{tabular}




\begin{tabular}{cccccc} 
Date & CPI & RTS & TNP & JCF & SP500 \\
\hline 11-Nov & 227.136 & 2.01 & 132632 & 392375 & 1246.96 \\
11-Dec & 227.093 & 1.98 & 132828 & 382650 & 1257.6 \\
12-Jan & 227.666 & 1.97 & 133188 & 383188 & 1312.41 \\
12-Feb & 228.138 & 1.97 & 133414 & 368938 & 1365.68 \\
12-Mar & 228.732 & 2.17 & 133657 & 367050 & 1408.47 \\
12-Apr & 229.184 & 2.05 & 133753 & 372813 & 1397.91 \\
12-May & 228.884 & 1.80 & 133863 & 373625 & 1310.33 \\
12-Jun & 228.825 & 1.62 & 133951 & 378450 & 1362.16 \\
12-Jul & 228.779 & 1.53 & 134111 & 371813 & 1379.32 \\
12-Aug & 229.952 & 1.68 & 134261 & 371000 & 1406.58 \\
12-Sep & 231.086 & 1.72 & 134422 & 380350 & 1440.67 \\
12-Oct & 231.652 & 1.75 & 134647 & 367063 & 1412.16 \\
12-Nov & 231.190 & 1.65 & 134850 & 388438 & 1416.18 \\
12-Dec & 231.099 & 1.72 & 135064 & 375050 & 1426.19 \\
13-Jan & 231.321 & 1.91 & 135261 & 362875 & 1498.11 \\
13-Feb & 232.599 & 1.98 & 135541 & 355000 & 1514.68 \\
13-Mar & 232.075 & 1.96 & 135682 & 347250 & 1569.19 \\
13-Apr & 231.707 & 1.76 & 135885 & 352813 & 1597.57 \\
13-May & 232.124 & 1.93 & 136084 & 341625 & 1630.74 \\
13-Jun & 232.860 & 2.30 & 136285 & 345950 & 1606.28 \\
13-Jul & 233.252 & 2.58 & 136434 & 345125 & 1685.73 \\
13-Aug & 233.433 & 2.74 & 136636 & 334700 & 1632.97 \\
13-Sep & 233.743 & 2.81 & 136800 & 320375 & 1681.55 \\
13-Oct & 233.782 & 2.62 & 137037 & 341063 & 1756.54 \\
13-Nov & 234.033 & 2.72 & 137311 & 339000 & 1805.81 \\
13-Dec & 234.594 & 2.90 & 137395 & 343063 & 1848.36 \\
14-Jan & 234.933 & 2.86 & 137539 & 338125 & 1782.59 \\
14-Feb & 235.169 & 2.71 & 137761 & 336500 & 1859.45 \\
14-Mar & 235.640 & 2.72 & 137964 & 327650 & 1872.34 \\
14-Apr & 236.254 & 2.71 & 138268 & 316438 & 1883.95 \\
14-May & 237.083 & 2.56 & 138497 & 318900 & 1923.57 \\
14-Jun & 237.693 & 2.60 & 138764 & 314375 & 1960.23
\end{tabular}




\section{Appendix B: Output Data and Forecast Results}

All train and validation data are combined in one table but validation data are bold and italic in the table.

\begin{tabular}{|c|c|c|c|c|}
\hline \multirow[b]{2}{*}{ Date } & \multicolumn{3}{|c|}{ Predicted } & \multirow{2}{*}{$\frac{\text { Actual }}{\mathrm{Y}}$} \\
\hline & MRL & ANN & SVR & \\
\hline Mar-93 & 6.8 & 6.7 & 6.9 & 7.0 \\
\hline Apr-93 & 6.7 & 6.6 & 7.0 & 7.1 \\
\hline May-93 & 7.0 & 6.9 & 7.0 & 7.1 \\
\hline Jun-93 & 7.0 & 6.9 & 6.9 & 7.0 \\
\hline Jul-93 & 6.8 & 6.8 & 6.9 & 6.9 \\
\hline Aug-93 & 6.8 & 6.7 & 6.9 & 6.8 \\
\hline Sep-93 & 6.7 & 6.7 & 6.8 & 6.7 \\
\hline Oct-93 & 6.9 & 6.8 & 6.8 & 6.8 \\
\hline Nov-93 & 6.7 & 6.6 & 6.7 & 6.6 \\
\hline Dec-93 & 6.8 & 6.7 & 6.6 & 6.5 \\
\hline Jan-94 & 6.7 & 6.6 & 6.6 & 6.6 \\
\hline Feb-94 & 6.4 & 6.4 & 6.6 & 6.6 \\
\hline Mar-94 & 6.5 & 6.4 & 6.5 & 6.5 \\
\hline Apr-94 & 6.7 & 6.6 & 6.4 & 6.4 \\
\hline May-94 & 6.3 & 6.2 & 6.3 & 6.1 \\
\hline Jun-94 & 6.1 & 6.0 & 6.1 & 6.1 \\
\hline Jul-94 & 6.2 & 6.1 & 6.0 & 6.1 \\
\hline Aug-94 & 6.1 & 6.0 & 6.0 & 6.0 \\
\hline Sep-94 & 6.0 & 5.9 & 5.9 & 5.9 \\
\hline Oct-94 & 5.9 & 5.8 & 5.8 & 5.8 \\
\hline Nov-94 & 5.8 & 5.7 & 5.8 & 5.6 \\
\hline Dec-94 & 5.7 & 5.6 & 5.7 & 5.5 \\
\hline Jan-95 & 5.5 & 5.4 & 5.6 & 5.6 \\
\hline Feb-95 & 5.5 & 5.4 & 5.6 & 5.4 \\
\hline Mar-95 & 5.5 & 5.4 & 5.6 & 5.4 \\
\hline Apr-95 & 5.5 & 5.4 & 5.6 & 5.8 \\
\hline May-95 & 5.6 & 5.5 & 5.6 & 5.6 \\
\hline Jun-95 & 5.7 & 5.6 & 5.6 & 5.6 \\
\hline Jul-95 & 6.0 & 5.9 & 5.7 & 5.7 \\
\hline Aug-95 & 6.1 & 6.0 & 5.7 & 5.7 \\
\hline Sep-95 & 6.1 & 6.0 & 5.7 & 5.6 \\
\hline Oct-95 & 5.9 & 5.8 & 5.6 & 5.5 \\
\hline Nov-95 & 5.9 & 5.9 & 5.6 & 5.6 \\
\hline Dec-95 & 6.0 & 5.9 & 5.6 & 5.6 \\
\hline
\end{tabular}




\begin{tabular}{|c|c|c|c|c|}
\hline \multirow[b]{2}{*}{ Date } & \multicolumn{3}{|c|}{ Predicted } & \multirow{2}{*}{$\begin{array}{c}\text { Actual } \\
\mathrm{Y}\end{array}$} \\
\hline & MRL & ANN & SVR & \\
\hline Jan-96 & 6.1 & 6.0 & 5.6 & 5.6 \\
\hline Feb-96 & 6.0 & 6.0 & 5.6 & 5.5 \\
\hline Mar-96 & 6.1 & 6.0 & 5.5 & 5.5 \\
\hline Apr-96 & 6.2 & 6.1 & 5.6 & 5.6 \\
\hline May-96 & 6.0 & 6.0 & 5.6 & 5.6 \\
\hline Jun-96 & 6.0 & 5.9 & 5.6 & 5.3 \\
\hline Jul-96 & 5.6 & 5.5 & 5.4 & 5.5 \\
\hline Aug-96 & 5.5 & 5.4 & 5.4 & 5.1 \\
\hline Sep-96 & 5.4 & 5.3 & 5.4 & 5.2 \\
\hline Oct-96 & 5.3 & 5.2 & 5.3 & 5.2 \\
\hline Nov-96 & 5.3 & 5.3 & 5.3 & 5.4 \\
\hline Dec-96 & 5.4 & 5.3 & 5.3 & 5.4 \\
\hline Jan-97 & 5.4 & 5.3 & 5.2 & 5.3 \\
\hline Feb-97 & 5.5 & 5.4 & 5.3 & 5.2 \\
\hline Mar-97 & 5.4 & 5.3 & 5.3 & 5.2 \\
\hline Apr-97 & 5.2 & 5.1 & 5.1 & 5.1 \\
\hline May-97 & 4.9 & 4.9 & 5.1 & 4.9 \\
\hline Jun-97 & 4.9 & 4.9 & 5.1 & 5.0 \\
\hline Jul-97 & 5.0 & 4.9 & 5.0 & 4.9 \\
\hline Aug-97 & 4.9 & 4.9 & 4.9 & 4.8 \\
\hline Sep-97 & 5.0 & 4.9 & 4.8 & 4.9 \\
\hline Oct-97 & 4.9 & 4.9 & 4.9 & 4.7 \\
\hline Nov-97 & 4.9 & 4.8 & 4.8 & 4.6 \\
\hline Dec-97 & 4.7 & 4.7 & 4.7 & 4.7 \\
\hline Jan-98 & 4.7 & 4.7 & 4.6 & 4.6 \\
\hline Feb-98 & 4.7 & 4.7 & 4.6 & 4.6 \\
\hline Mar-98 & 4.7 & 4.7 & 4.6 & 4.7 \\
\hline Apr-98 & 4.7 & 4.7 & 4.5 & 4.3 \\
\hline May-98 & 4.7 & 4.6 & 4.5 & 4.4 \\
\hline Jun-98 & 4.6 & 4.6 & 4.4 & 4.5 \\
\hline Jul-98 & 4.4 & 4.4 & 4.4 & 4.5 \\
\hline Aug-98 & 4.6 & 4.6 & 4.5 & 4.5 \\
\hline Sep-98 & 4.9 & 4.8 & 4.7 & 4.6 \\
\hline Oct-98 & 4.4 & 4.4 & 4.6 & 4.5 \\
\hline Nov-98 & 4.3 & 4.4 & 4.5 & 4.4 \\
\hline Dec-98 & 4.4 & 4.4 & 4.5 & 4.4 \\
\hline Jan-99 & 4.4 & 4.4 & 4.4 & 4.3 \\
\hline Feb-99 & 4.4 & 4.4 & 4.5 & 4.4 \\
\hline Mar-99 & 4.6 & 4.5 & 4.5 & 4.2 \\
\hline Apr-99 & 4.2 & 4.2 & 4.3 & 4.3 \\
\hline
\end{tabular}




\begin{tabular}{|c|c|c|c|c|}
\hline \multirow[b]{2}{*}{ Date } & \multicolumn{3}{|c|}{ Predicted } & \multirow{2}{*}{$\frac{\text { Actual }}{\mathrm{Y}}$} \\
\hline & MRL & ANN & SVR & \\
\hline May-99 & 4.1 & 4.2 & 4.3 & 4.2 \\
\hline Jun-99 & 4.2 & 4.3 & 4.3 & 4.3 \\
\hline Jul-99 & 4.0 & 4.2 & 4.2 & 4.3 \\
\hline Aug-99 & 3.9 & 4.1 & 4.1 & 4.2 \\
\hline Sep-99 & 3.8 & 4.0 & 4.1 & 4.2 \\
\hline Oct-99 & 3.8 & 4.0 & 4.1 & 4.1 \\
\hline Nov-99 & 3.7 & 3.9 & 4.1 & 4.1 \\
\hline Dec-99 & 3.7 & 4.0 & 4.1 & 4.0 \\
\hline Jan-00 & 3.6 & 3.9 & 4.1 & 4.0 \\
\hline Feb-00 & 3.5 & 3.9 & 4.1 & 4.1 \\
\hline Mar-00 & 3.4 & 3.8 & 4.1 & 4.0 \\
\hline Apr-00 & 3.6 & 3.9 & 4.1 & 3.8 \\
\hline May-00 & 3.5 & 3.8 & 4.1 & 4.0 \\
\hline Jun-00 & 3.3 & 3.7 & 4.1 & 4.0 \\
\hline Jul-00 & 3.3 & 3.7 & 4.0 & 4.0 \\
\hline Aug-00 & 3.5 & 3.8 & 4.0 & 4.1 \\
\hline Sep-00 & 3.6 & 3.9 & 3.9 & 3.9 \\
\hline Oct-00 & 3.8 & 4.0 & 3.9 & 3.9 \\
\hline Nov-00 & 3.8 & 4.0 & 3.9 & 3.9 \\
\hline Dec-00 & 3.7 & 3.9 & 3.9 & 3.9 \\
\hline Jan-01 & 3.8 & 4.0 & 4.0 & 4.2 \\
\hline Feb-01 & 4.2 & 4.2 & 4.1 & 4.2 \\
\hline Mar-01 & 4.3 & 4.3 & 4.2 & 4.3 \\
\hline Apr-01 & 4.4 & 4.4 & 4.5 & 4.4 \\
\hline May-01 & 4.7 & 4.5 & 4.8 & 4.3 \\
\hline Jun-01 & 4.8 & 4.6 & 4.8 & 4.5 \\
\hline Jul-01 & 4.9 & 4.7 & 4.9 & 4.6 \\
\hline Aug-01 & 5.1 & 4.8 & 5.0 & 4.9 \\
\hline Sep-01 & 5.0 & 4.8 & 5.0 & 5.0 \\
\hline Oct-01 & 5.1 & 4.9 & 5.1 & 5.3 \\
\hline Nov-01 & 5.3 & 5.1 & 5.4 & 5.5 \\
\hline Dec-01 & 6.2 & 5.7 & 5.8 & 5.7 \\
\hline Jan-02 & 6.0 & 5.6 & 5.7 & 5.7 \\
\hline Feb-02 & 5.7 & 5.4 & 5.6 & 5.7 \\
\hline Mar-02 & 5.5 & 5.3 & 5.5 & 5.7 \\
\hline Apr-02 & 5.4 & 5.3 & 5.4 & 5.9 \\
\hline May-02 & 5.5 & 5.3 & 5.5 & 5.8 \\
\hline Jun-02 & 5.9 & 5.7 & 5.9 & 5.8 \\
\hline Jul-02 & 5.6 & 5.5 & 5.7 & 5.8 \\
\hline Aug-02 & 5.4 & 5.3 & 5.6 & 5.7 \\
\hline
\end{tabular}




\begin{tabular}{|c|c|c|c|c|}
\hline \multirow[b]{2}{*}{ Date } & \multicolumn{3}{|c|}{ Predicted } & \multirow{2}{*}{$\begin{array}{c}\text { Actual } \\
\mathrm{Y}\end{array}$} \\
\hline & MRL & ANN & SVR & \\
\hline Sep-02 & 5.3 & 5.3 & 5.7 & 5.7 \\
\hline Oct-02 & 5.4 & 5.5 & 5.7 & 5.7 \\
\hline Nov-02 & 5.6 & 5.8 & 5.9 & 5.9 \\
\hline Dec-02 & 5.7 & 5.7 & 5.8 & 6.0 \\
\hline Jan-03 & 5.6 & 5.7 & 5.7 & 5.8 \\
\hline Feb-03 & 5.7 & 5.8 & 5.8 & 5.9 \\
\hline Mar-03 & 5.6 & 5.8 & 5.9 & 5.9 \\
\hline Apr-03 & 5.8 & 6.0 & 6.0 & 6.0 \\
\hline May-03 & 6.1 & 6.2 & 6.1 & 6.1 \\
\hline Jun-03 & 6.2 & 6.2 & 6.1 & 6.3 \\
\hline Jul-03 & 6.2 & 6.2 & 6.0 & 6.2 \\
\hline Aug-03 & 6.2 & 6.2 & 6.0 & 6.1 \\
\hline Sep-03 & 6.1 & 6.1 & 6.0 & 6.1 \\
\hline Oct-03 & 5.9 & 6.0 & 6.0 & 6.0 \\
\hline Nov-03 & 6.0 & 6.0 & 6.0 & 5.8 \\
\hline Dec-03 & 5.7 & 5.7 & 5.8 & 5.7 \\
\hline Jan-04 & 5.6 & 5.6 & 5.7 & 5.7 \\
\hline Feb-04 & 5.5 & 5.6 & 5.6 & 5.6 \\
\hline Mar-04 & 5.5 & 5.5 & 5.6 & 5.8 \\
\hline Apr-04 & 5.6 & 5.6 & 5.7 & 5.6 \\
\hline May-04 & 5.4 & 5.4 & 5.6 & 5.6 \\
\hline Jun-04 & 5.3 & 5.3 & 5.4 & 5.6 \\
\hline Jul-04 & 5.1 & 5.2 & 5.3 & 5.5 \\
\hline Aug-04 & 5.2 & 5.3 & 5.3 & 5.4 \\
\hline Sep-04 & 5.2 & 5.3 & 5.4 & 5.4 \\
\hline Oct-04 & 5.2 & 5.3 & 5.4 & 5.5 \\
\hline Nov-04 & 5.2 & 5.3 & 5.4 & 5.4 \\
\hline Dec-04 & 5.2 & 5.3 & 5.4 & 5.4 \\
\hline Jan-05 & 5.1 & 5.2 & 5.3 & 5.3 \\
\hline Feb-05 & 5.1 & 5.2 & 5.3 & 5.4 \\
\hline Mar-05 & 5.2 & 5.2 & 5.2 & 5.2 \\
\hline Apr-05 & 4.9 & 5.1 & 5.2 & 5.2 \\
\hline May-05 & 5.0 & 5.1 & 5.1 & 5.1 \\
\hline Jun-05 & 5.0 & 5.1 & 5.1 & 5.0 \\
\hline Jul-05 & 4.9 & 5.0 & 5.1 & 5.0 \\
\hline Aug-05 & 4.9 & 5.0 & 5.0 & 4.9 \\
\hline Sep-05 & 4.9 & 4.9 & 4.9 & 5.0 \\
\hline Oct-05 & 4.8 & 4.9 & 4.9 & 5.0 \\
\hline Nov-05 & 5.4 & 5.4 & 5.2 & 5.0 \\
\hline Dec-05 & 5.6 & 5.5 & 5.2 & 4.9 \\
\hline
\end{tabular}




\begin{tabular}{|c|c|c|c|c|}
\hline \multirow[b]{2}{*}{ Date } & \multicolumn{3}{|c|}{ Predicted } & \multirow{2}{*}{$\frac{\text { Actual }}{\mathrm{Y}}$} \\
\hline & MRL & ANN & SVR & \\
\hline Jan-06 & 4.8 & 4.9 & 4.7 & 4.7 \\
\hline Feb-06 & 4.8 & 4.9 & 4.7 & 4.8 \\
\hline Mar-06 & 4.7 & 4.8 & 4.8 & 4.7 \\
\hline Apr-06 & 4.4 & 4.6 & 4.7 & 4.7 \\
\hline May-06 & 4.5 & 4.6 & 4.6 & 4.6 \\
\hline Jun-06 & 4.4 & 4.6 & 4.5 & 4.6 \\
\hline Jul-06 & 4.8 & 4.8 & 4.5 & 4.7 \\
\hline Aug-06 & 4.6 & 4.7 & 4.6 & 4.7 \\
\hline Sep-06 & 4.7 & 4.8 & 4.6 & 4.5 \\
\hline Oct-06 & 4.7 & 4.8 & 4.6 & 4.4 \\
\hline Nov-06 & 4.6 & 4.7 & 4.5 & 4.5 \\
\hline Dec-06 & 4.6 & 4.6 & 4.5 & 4.4 \\
\hline Jan-07 & 4.7 & 4.6 & 4.5 & 4.6 \\
\hline Feb-07 & 4.8 & 4.7 & 4.5 & 4.5 \\
\hline Mar-07 & 4.7 & 4.6 & 4.5 & 4.4 \\
\hline Apr-07 & 4.6 & 4.6 & 4.4 & 4.5 \\
\hline Мay-07 & 4.7 & 4.6 & 4.5 & 4.4 \\
\hline Jun-07 & 4.8 & 4.7 & 4.6 & 4.6 \\
\hline Jul-07 & 4.7 & 4.6 & 4.7 & 4.7 \\
\hline Aug-07 & 4.7 & 4.6 & 4.7 & 4.6 \\
\hline Sep-07 & 4.7 & 4.6 & 4.6 & 4.7 \\
\hline Oct-07 & 4.8 & 4.7 & 4.7 & 4.7 \\
\hline Nov-07 & 4.9 & 4.7 & 4.9 & 4.7 \\
\hline Dec-07 & 5.0 & 4.8 & 4.9 & 5.0 \\
\hline Jan-08 & 5.2 & 4.9 & 5.0 & 5.0 \\
\hline Feb-08 & 5.3 & 5.0 & 5.0 & 4.9 \\
\hline Mar-08 & 5.4 & 5.1 & 5.1 & 5.1 \\
\hline Apr-08 & 5.4 & 5.2 & 5.1 & 5.0 \\
\hline May-08 & 5.6 & 5.3 & 5.3 & 5.4 \\
\hline Jun-08 & 5.8 & 5.5 & 5.5 & 5.6 \\
\hline Jul-08 & 5.9 & 5.5 & 5.5 & 5.8 \\
\hline Aug-08 & 6.1 & 5.9 & 5.7 & 6.1 \\
\hline Sep-08 & 6.4 & 6.2 & 6.0 & 6.1 \\
\hline Oct-08 & 6.9 & 6.6 & 6.6 & 6.5 \\
\hline Nov-08 & 7.2 & 7.0 & 7.0 & 6.8 \\
\hline Dec-08 & 7.4 & 7.3 & 7.3 & 7.3 \\
\hline Jan-09 & 7.7 & 7.6 & 7.8 & 7.8 \\
\hline Feb-09 & 8.5 & 8.0 & 8.5 & 8.3 \\
\hline Mar-09 & 8.7 & 8.4 & 8.7 & 8.7 \\
\hline Apr-09 & 9.6 & 9.2 & 9.1 & 9.0 \\
\hline
\end{tabular}




\begin{tabular}{|c|c|c|c|c|}
\hline \multirow[b]{2}{*}{ Date } & \multicolumn{3}{|c|}{ Predicted } & \multirow{2}{*}{$\begin{array}{c}\text { Actual } \\
\mathrm{Y}\end{array}$} \\
\hline & MRL & ANN & SVR & \\
\hline May-09 & 10.1 & 9.6 & 9.1 & 9.4 \\
\hline Jun-09 & 10.2 & 9.8 & 9.3 & 9.5 \\
\hline Jul-09 & 10.0 & 9.8 & 9.6 & 9.5 \\
\hline Aug-09 & 10.0 & 10.0 & 9.7 & 9.6 \\
\hline Sep-09 & 9.8 & 9.9 & 9.8 & 9.8 \\
\hline Oct-09 & 9.7 & 9.9 & 9.8 & 10.0 \\
\hline Nov-09 & 9.8 & 9.9 & 9.9 & 9.9 \\
\hline Dec-09 & 9.6 & 9.9 & 9.9 & 9.9 \\
\hline Jan-10 & 9.4 & 9.8 & 9.9 & 9.7 \\
\hline Feb-10 & 9.2 & 9.7 & 9.8 & 9.8 \\
\hline Mar-10 & 9.0 & 9.6 & 9.6 & 9.9 \\
\hline Apr-10 & 9.1 & 9.7 & 9.7 & 9.9 \\
\hline May-10 & 9.1 & 9.5 & 9.6 & 9.6 \\
\hline Jun-10 & 8.9 & 9.3 & 9.4 & 9.4 \\
\hline Jul-10 & 8.6 & 9.2 & 9.3 & 9.5 \\
\hline Aug-10 & 8.7 & 9.2 & 9.3 & 9.5 \\
\hline Sep-10 & 8.7 & 9.2 & 9.4 & 9.5 \\
\hline Oct-10 & 9.0 & 9.5 & 9.5 & 9.5 \\
\hline Nov-10 & 8.9 & 9.3 & 9.4 & 9.8 \\
\hline Dec-10 & 8.8 & 9.2 & 9.3 & 9.4 \\
\hline Jan-11 & 8.6 & 9.0 & 9.2 & 9.1 \\
\hline Feb-11 & 8.5 & 9.0 & 9.2 & 9.0 \\
\hline Mar-11 & 8.6 & 9.0 & 9.2 & 9.0 \\
\hline Apr-11 & 8.5 & 8.9 & 9.0 & 9.1 \\
\hline May-11 & 8.4 & 8.8 & 9.0 & 9.0 \\
\hline Jun-11 & 8.4 & 8.7 & 8.9 & 9.1 \\
\hline Jul-11 & 8.7 & 9.0 & 9.2 & 9.0 \\
\hline Aug-11 & 8.5 & 8.9 & 9.0 & 9.0 \\
\hline Sep-11 & 8.5 & 8.9 & 9.0 & 9.0 \\
\hline Oct-11 & 8.5 & 8.9 & 8.8 & 8.8 \\
\hline Nov-11 & 8.5 & 8.9 & 8.5 & 8.6 \\
\hline Dec-11 & 8.4 & 8.7 & 8.6 & 8.5 \\
\hline Jan-12 & 8.3 & 8.6 & 8.4 & 8.2 \\
\hline Feb-12 & 8.1 & 8.5 & 8.3 & 8.3 \\
\hline Mar-12 & 8.1 & 8.3 & 8.3 & 8.2 \\
\hline Apr-12 & 7.9 & 8.1 & 8.1 & 8.2 \\
\hline May-12 & 7.9 & 8.1 & 8.1 & 8.2 \\
\hline Jun-12 & 8.0 & 8.1 & 8.1 & 8.2 \\
\hline Jul-12 & 7.9 & 8.1 & 8.0 & 8.2 \\
\hline Aug-12 & 8.0 & 8.1 & 7.9 & 8.1 \\
\hline
\end{tabular}




\begin{tabular}{|c|c|c|c|c|}
\hline \multirow[b]{2}{*}{ Date } & \multicolumn{3}{|c|}{ Predicted } & \multirow{2}{*}{$\begin{array}{c}\text { Actual } \\
\mathrm{Y}\end{array}$} \\
\hline & MRL & ANN & SVR & \\
\hline Sep-12 & 7.9 & 7.9 & 7.8 & 7.8 \\
\hline Oct-12 & 7.9 & 8.0 & 7.9 & 7.8 \\
\hline Nov-12 & 8.1 & 8.1 & 7.9 & 7.8 \\
\hline Dec-12 & 7.9 & 7.9 & 7.8 & 7.9 \\
\hline Jan-13 & 8.1 & 8.0 & 7.8 & 7.9 \\
\hline Feb-13 & 7.9 & 7.7 & 7.7 & 7.7 \\
\hline Mar-13 & 7.7 & 7.6 & 7.6 & 7.5 \\
\hline Apr-13 & 7.7 & 7.5 & 7.6 & 7.5 \\
\hline May-13 & 7.5 & 7.3 & 7.4 & 7.5 \\
\hline Jun-13 & 7.6 & 7.3 & 7.3 & 7.5 \\
\hline Jul-13 & 7.4 & 7.1 & 7.2 & 7.3 \\
\hline Aug-13 & 7.4 & 7.2 & 7.3 & 7.2 \\
\hline Sep-13 & 7.4 & 7.1 & 7.1 & 7.2 \\
\hline Oct-13 & 7.2 & 7.0 & 7.1 & 7.2 \\
\hline Nov-13 & 7.0 & 6.8 & 6.9 & 7.0 \\
\hline Dec-13 & 7.3 & 6.8 & 6.8 & 6.7 \\
\hline Jan-14 & 7.2 & 6.7 & 6.6 & 6.6 \\
\hline Feb-14 & 7.3 & 6.8 & 6.5 & 6.7 \\
\hline Mar-14 & 7.2 & 6.8 & 6.6 & 6.7 \\
\hline Apr-14 & 7.2 & 6.6 & 6.4 & 6.3 \\
\hline May-14 & 7.1 & 6.5 & 6.3 & 6.3 \\
\hline Jun-14 & 6.9 & 6.4 & 6.2 & 6.1 \\
\hline Jul-14 & 7.0 & 6.4 & 6.1 & 6.2 \\
\hline Aug-14 & 6.9 & 6.3 & 6.0 & 6.1 \\
\hline
\end{tabular}

